РЕВИЗИЯ БИОРАЗНООБРАЗИЯ КРУПНОГО АРКТИЧЕСКОГО РЕГИОНА КАК ОСНОВА ЕГО МОНИТОРИНГА И ОХРАНЫ В УСЛОВИЯХ АКТИВНОГО ХОЗЯЙСТВЕННОГО ОСВОЕНИЯ (НЕНЕЦКИЙ АВТОНОМНЫЙ ОКРУГ, РОССИЯ)

\author{
В. В. Рожнов ${ }^{1}$, И. А. Лавриненко ${ }^{2}$, В. Ю. Разживин ${ }^{2}$, О. Л. Макарова ${ }^{1, *}$, \\ О. В. Лавриненко ${ }^{2}$ В. В. Ануфриев ${ }^{3}$, А. Б. Бабенко ${ }^{1}$, М. С. Бизин ${ }^{1}$, П. М. Глазов ${ }^{4}$, \\ С. В. Горячкин ${ }^{4}$, А. А. Колесникова ${ }^{5}$, Н. В. Матвеева ${ }^{2}$, С. В. Пестов ${ }^{5}$, \\ В. В. Петровский ${ }^{2}$ О. Б. Покровская ${ }^{1}$, А. В. Танасевич ${ }^{1}$, А. Г. Татаринов ${ }^{5}$ \\ ${ }^{1}$ Институт проблем экологии и эволючии им. А.Н. Севериова РАН, Россия \\ ${ }^{2}$ Ботанический институт им. В.Л. Комарова РАН, Россия \\ ${ }^{3}$ Федеральный исследовательский иентр комплексного изучения Арктики им. Н.П. Лаверова РАН, Россия \\ ${ }^{4}$ Институт географии РАН, Россия \\ ${ }^{5}$ Институт биологии Коми НЦ УрО РАН, Россия \\ *e-mail: ol_makarova@mail.ru
}

Поступила: 18.03.2018. Исправлена: 26.01.2019. Принята к опубликованию: 14.02.2019.

\begin{abstract}
В рамках проекта ПРООН/ГЭФ и Минприроды России созданы база данных и ГИС по биологическому разнообразию Ненецкого автономного округа (НАО), включающие сведения о 2035 видах животных и 1640 видах растений 15 модельных групп. Они были получены из опубликованных и архивных данных, коллекционных и гербарных материалов четырех институтов РАН, а также в результате экспедиционных сборов 2015 г. в трех приморских районах Большеземельской тундры. Установлено, что таксономическое разнообразие биоты НАО в целом не ниже, а по некоторым группам животных выше, чем в других крупных арктических регионах, таких, например, как Таймыр и Гренландия. Описаны новые синтаксоны растительности, установлены некоторые фитогеографические рубежи, выявлены таксоны животных: новые для науки, ранее не отмечавшиеся в НАО и впервые найденные в Европе («сибирские» виды) или в России. Доля видов с преимущественно сибирским, восточнопалеарктическим или сибиро-неарктическим распространением колеблется в отдельных модельных группах от 0\% до 30\%; доля арктических (в широком смысле) видов варьирует от 0\% до 29\%. Отмечено удовлетворительное состояние природной среды в округе, ее нарушения до сих пор сугубо локальны. Подтверждена необходимость создания новых особо охраняемых природных территорий. Материалы, полученные в рамках проекта, были привлечены для обоснования заказников в районах Хайпудырской и Паханческой губ, Баренцево море.
\end{abstract}

Ключевые слова: биологическая ценность, геоботаническое районирование, карта, локальная флора, марши, ООПТ, техногенное воздействие, фауна, флора

\section{Введение}

Ненецкий автономный округ (НАО) крупный (176810 км²) регион на северо-востоке европейской части России, почти целиком (за исключением крайней юго-западной части) расположенный севернее Полярного круга. Он простирается с запада на восток почти на 1000 км, имеет протяженное (более 3000 км) морское побережье и омывается водами Белого, Баренцева и Карского морей Северного Ледовитого океана. Кроме материковой части НАО включает крупные (Колгуев и Вайгач) и несколько малых островов. На относитель- но небольшом (300-400 км) меридиональном отрезке происходит смена шести природных подзон и полос - арктические, типичные и южные тундры, северная и южная лесотундры и северная тайга (рис. 1).

Округ малонаселен, в нем проживает около 42000 человек, половина из них - в административном центре - г. Нарьян-Мар. При столь низкой плотности населения нагрузка на природные экосистемы до середины прошлого века была обусловлена ведением традиционных отраслей сельского хозяйства, главным образом, оленеводства. Численность оленей в разные годы ко- 
лебалась в пределах 140 000-220 000 голов. И, при соблюдении регламентированной нагрузки и пастбищеоборота, такое поголовье не наносило значительного ущерба природной среде. С 1970-х гг. началась активная разведка углеводородов, пробурено более 1500 скважин, открыто 89 месторождений, в которых сосредоточено 1.2 млрд. тонн запасов нефти и 525 млрд. м ${ }^{3}$ газа (Анненкова, 2010). Открытые в советский период нефтяные месторождения с 1990-х гг. интенсивно осваиваются. И к настоящему времени в округе сложилась ситуация, когда оленеводство конкурирует с нефтедобывающими компаниями за землю. Так, с 1995 г. по 2006 г. из фонда оленьих пастбищ для промышленных нужд выведено 4579 км² (3.3\% общей площади пастбищ,

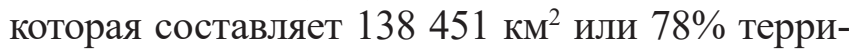
тории округа) (Стратегия социально-экономического развития..., 2008-2009).
Изъятие части пастбищ ведет к усилению пастбищной нагрузки на участки, оставшиеся в пользовании оленеводческих хозяйств, что приводит к перевыпасу и истощению, прежде всего, лишайниковых пастбищ. Учитывая продолжительность снежного сезона в НАО, именно их состояние является лимитирующим фактором для развития оленеводства. Ситуация с лишайниковыми пастбищами в целом по округу не критична, хотя отмечены районы, например, о-в Колгуев, где они уничтожены почти полностью (Лавриненко, Лавриненко, 2014). Сейчас большинство лицензионных участков недропользователей сосредоточено на территории Большеземельской тундры. Но в последние годы их предоставляют и в восточных районах НАО, и западнее - в Малоземельской тундре, а также на шельфе Баренцева моря.

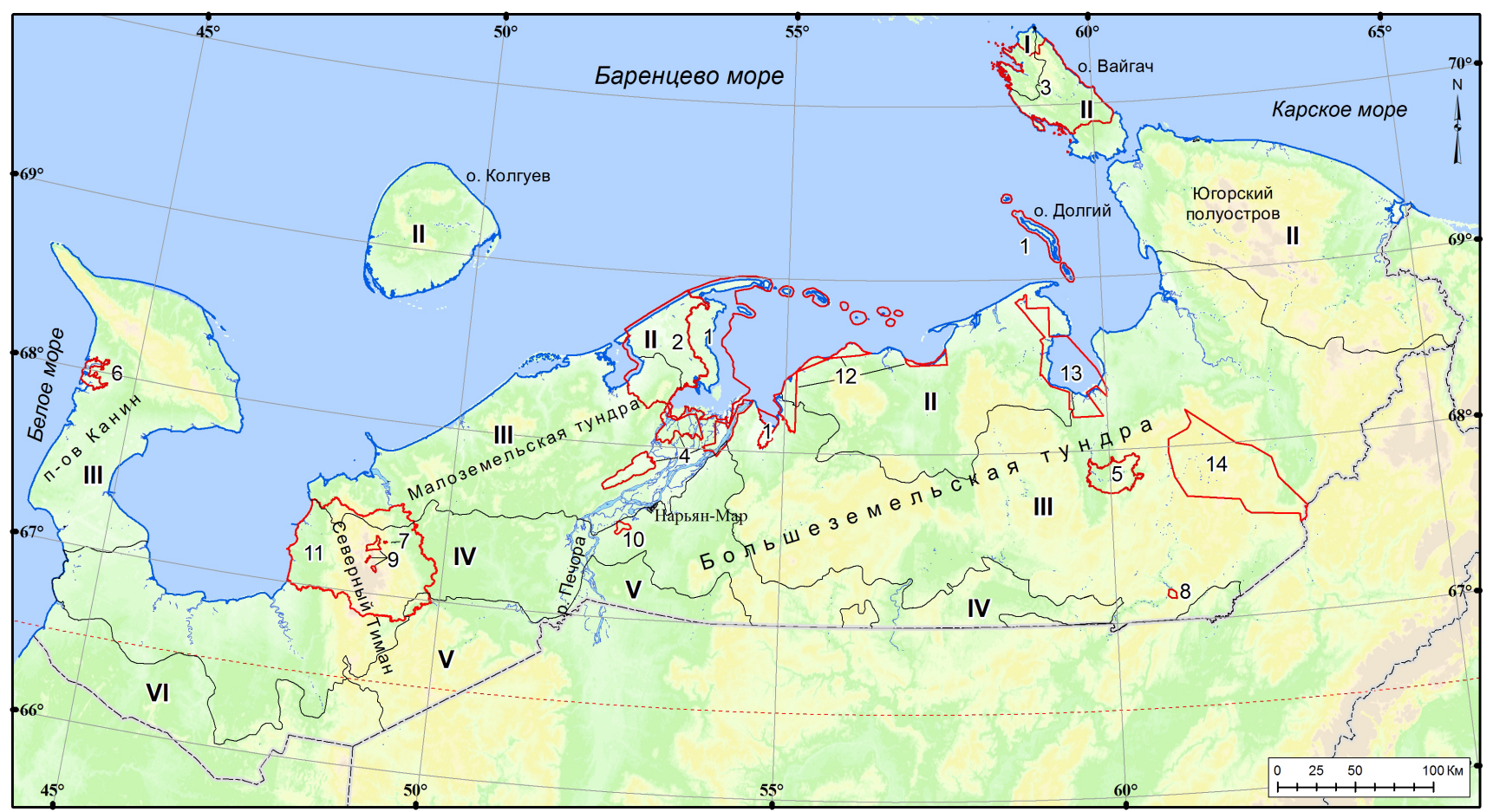

Рис. 1. Природная зональность и особо охраняемые природные территории в административных границах Ненецкого автономного округа. Федеральные ООПТ: 1 - заповедник «Ненецкий», 2 - заказник «Ненецкий». Региональные ООПТ: 3 - заказник «Вайгач», 4 - заказник «Нижнепечорский», 5 - заказник «Море-Ю», 6 - заказник «Шоинский», 12 - заказник «Паханческий», 13 - заказник «Хайпудырский», 14 - заказник «Вашуткинский»; 11 - природный парк «Северный Тиман»; 7 - памятник природы «Каньон “Большие ворота”», 8 - памятник природы «Пым-Ва-Шор», 9 памятник природы «Каменный город»; 10 - Пустозерский историко-природный музей. Подзоны и полосы: I - арктические тундры, II - типичные тундры, III - южные тундры, IV - северная лесотундра, V - южная лесотундра, VI - северная тайга; тонкие сплошные линии - границы между ними, пунктирная линия - административная граница НАО. Fig. 1. Natural zonality and Protected Areas within the Nenetsky Autonomous Okrug. Federal-level Protected Areas: $1-\mathrm{Ne}-$ netsky State Nature Reserve, 2 - Nenetsky Sanctuary. Regional-level Protected Areas: 3 - Sanctuary «Vaigach», 4 - Sanctuary «Nizhnepechorsky», 5 - Sanctuary «More-Yu», 6 - Sanctuary «Shoinsky», 12 - Sanctuary «Pakhanchesky», 13 - Sanctuary «Khaypudyrsky», 14 - Sanctuary «Vashutkinsky»; 11 - North Timan Natural Park; 7 - Natural Monument «Grand Gate Canyon», 8 - Natural Monument «Pym-Va-Shor», 9 - Natural Monument «Stone City»; 10 - Pustozersky Historical-Natural Museum. Subzones and belts: I - arctic tundra, II - typical tundra, III - southern tundra, IV - northern forest-tundra, V - southern forest-tundra, VI - northern taiga; thin solid lines indicate their boundaries, dotted line corresponds to the administrative boundary of the Nenetsky Autonomous Okrug. 
Техногенные воздействия на природные экосистемы приводят к снижению биологического разнообразия на всех уровнях - видовом, ценотическом, ландшафтном. Именно состояние биоразнообразия является главным критерием и признаком устойчивости экосистем, а его сохранение - одной из приоритетных задач современности. Осознание этой необходимости на международном уровне нашло отражение в принятии Конвенции о сохранении биологического разнообразия (Всемирная конференция глав государств ООН по окружающей среде и развитию, Рио-де-Жанейро, 5 июня 1992 г.), которую Россия ратифицировала в 1995 г. В это же время проблеме охраны природных экосистем было уделено внимание российских исследователей восточноевропейских тундр (Программный проект..., 1992). Работы по изучению биологического разнообразия в Арктике особенно активизировались в последние десятилетия (Matveyeva \& Chernov, 2000; Callaghan et al., 2004; Bellard et al., 2012; Meltofte, 2013; Coulson et al., 2014).

Территория НАО важна для сохранения и поддержания биоразнообразия бассейна Баренцева моря и Арктики в целом как в качественном, так и в количественном аспектах. Восточноевропейские тундры - «транзитный коридор» для водоплавающих и околоводных птиц, летящих одним из важнейших в Арктике Восточно-Атлантическим миграционным путем. На территории округа выделено 13 участков, включенных в перспективный (теневой) список водно-болотных угодий Рамсарской Конвенции с международным статусом охраны (Кривенко, 2000). Десять из них расположены в приморских районах. Тундры являются местами концентрации эндемичных и редких арктических видов животных и растений. В Красную книгу Ненецкого автономного округа (2006) включено 225 видов: 123 - растений, 66 - животных и 36 - грибов (включая лишайники). В соответствии с законодательством, проведены работы по переизданию Красной книги Ненецкого автономного округа. В результате были пересмотрены категории охраняемых видов, дополнены списки редких и исчезающих видов согласно критериям Красного списка МСОП (см. также Ручин, Егоров, 2017; Хапугин и др., 2017).

Одним из ключевых механизмов сохранения биоразнообразия арктических регионов является развитие системы особо охраняемых природных территорий (ООПТ) (Гаврило, Мартынова, 2017). К началу 2017 г. в НАО было создано десять ООПТ общей площадью 10340 км², частично (1820 км²) охватывающих морскую акваторию (Лавриненко и др., 2015). Под охраной находилось менее 5\% суши НАО, что ничтожно мало в условиях активного промышленного освоения территории. В 2017-2018 гг. были созданы природный парк «Северный Тиман», заказники «Паханческий», «Хайпудырский» и «Вашуткинский». Это увеличило охраняемую площадь суши НАО до $10.4 \%$, а площадь охра-

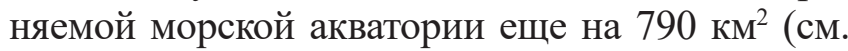
рис. 1). В период до 2030 г. запланировано организовать в округе еще один природный парк и пять региональных заказников.

Цели поддержания глобально значимого биологического разнообразия российской Арктики требуют разработки и внесения в законодательство и нормативно-правовую базу изменений. Они обяжут компании энергетического комплекса организовывать свою деятельность с учетом необходимости его сохранения.

В 2014-2016 гг. в НАО действовал проект ПРООН/ГЭФ и Минприроды России «Задачи сохранения биоразнообразия в политике и программах развития энергетического сектора России» (Договор №19/K/2014 от 20 ноября 2014 г.). Цель его - собрать все имеющиеся на настоящий момент данные по флоре и фауне региона и с помощью современных технологий (базы данных (БД), геоинформационные системы (ГИС), материалы спутниковых снимков) ранжировать отдельные географические выделы по их значимости для сохранения биоразнообразия при организации хозяйственной деятельности. Его исполнителями были переработаны и приведены в систему огромные объемы доступной для НАО информации по биоразнообразию, а также в ходе экспедиционных работ получены новые сведения по растительности, флоре и фауне.

Цель статьи - изложить результаты инвентаризации биоты НАО (15 модельных групп: сосудистые растения, мхи, печеночники, лишайники, беспозвоночные, птицы, млекопитающие) и показать возможность их использования для дифференцированной оценки территории с учетом видового богатства и распространения отдельных видов модельных групп по районам.

\section{Материал и методы}

В программе EndNote была создана библиографическая БД, включающая 1418 печатных источников с 1805 по 2016 гг., в которых есть 
данные о флоре и фауне НАО. Библиографическая БД передана в КУ НАО Ненецкий информационно-аналитический центр. В последующем на ее основе возможно создание электронной библиотеки по биоразнообразию НАО. Сейчас содержащиеся в базе pdf-файлы включают важнейшие литературные источники и публикации исполнителей проекта. Материалы были не просто собраны, но и проанализированы, достоверность сведений о местонахождениях видов была подтверждена по коллекциям и гербариям Ботанического института РАН, Института проблем экологии и эволюции РАН, Института биологии Коми УрО РАН и Института экологических проблем Севера УрО РАН. В 80\% случаев указания видов имели географическую привязку, с указанием координат или она могла быть определена косвенными методами.

Основной упор был сделан на биоразнообразии 15 основных (модельных) групп организмов (сосудистые растения, лишайники, мхи, печеночники, дождевые черви, клещи, пауки, ногохвостки, клопы, жуки, двукрылые, дневные бабочки, шмели, птицы, наземные млекопитающие), выбор которых определен по следующим критериям:

1) большое биоценотическое значение;

2) высокая информативность и пригодность для биоиндикации состояния наземных экосистем;

3) возможность сбора значительного материала и наличие специалистов для его обработки (в том числе определения таксономической принадлежности).

Для каждой анализируемой группы флоры/ фауны оценены общее видовое богатство на территории НАО, таксономическая структура и соотношение ареалогических групп.

В июле - августе 2015 г. были проведены экспедиционные работы в три малоизученных прибрежных района Большеземельской тундры - Болванскую, Паханческую и Хайпудырскую губы (рис. 2). Непосредственно в полевых исследованиях участвовало большинство соавторов этой статьи, другие же приняли участие в обработке собранного материала.

Полевые ботанические исследования включали: геоботанические описания зональных и интразональных сообществ в традициях школы Браун-Бланке, регистрацию и составление локальных перечней видов сосудистых растений, мхов и лишайников при их целенаправленных поисках маршрутным методом и при выполнении геоботанических описаний, сбор гербария трудно определимых таксонов для последующей камеральной идентификации, полевое дешифрирование спутниковых снимков. Зоологические работы состояли из: учетов (водных и пеших маршрутных, площадочных) млекопитающих и птиц в разных типах местообитаний, кольцевания и наблюдения меченых птиц; ручного разбора почвенных проб; установки почвенных, водных и оконных ловушек, «желтых тарелок»; кошения энтомологическим сачком, флотации, сифтования, выгонки членистоногих в эклектоpax Тульгрена. Полученные новые данные о местонахождениях и состоянии популяций видов растений и животных позволили значительно пополнить БД по модельным группам организмов и подробно описать экосистемы прибрежных районов Большеземельской тундры с особым вниманием к сообществам маршевого комплекса.

Оценка всего разнообразия животного и растительного мира была бы невозможной без применения современных технологий. Объектно-ориентированные БД по всем учитываемым компонентам биоты (выполненные в среде MS Access) сведены в единую ГИСориентированную аналитическую БД по биологическому разнообразию НАО. Это сделало возможным их визуализацию на многослойной карте в среде ArcGIS и создание информационной системы в Интернете. База данных подготовлена на основе документированных местонахождений (геоданные) и содержит всю доступную информацию о биологии, экологии и распространении по территории НАО всех видов животных и растений модельных групп.

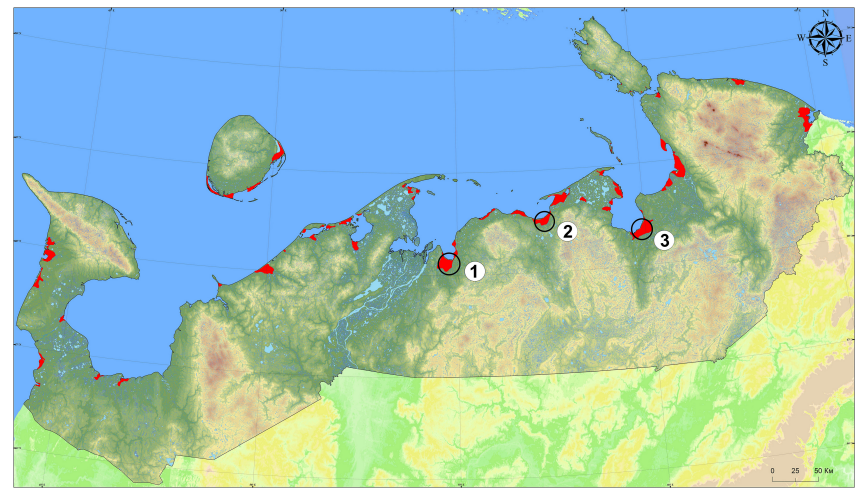

Рис. 2. Распространение приморских маршей (обозначено красным по: Лавриненко, 2012а) в Ненецком автономном округе и районы работ экспедиции 2015 г. Губы: 1 - Болванская, 2 - Паханческая, 3 - Хайпудырская.

Fig. 2. The distribution of sea coastal marshes (marked by red colour according to Lavrinenko, 2012a) in the Nenetsky Autonomous Okrug and the area of fieldwork in 2015. Designations: 1 - Bolvanskaya Bay, 2 - Pakhancheskaya Bay, 3 - Khaipudyrskaya Bay. 
При создании карты техногенной нарушенности растительного покрова НАО по материалам многозональных спутниковых снимков Landsat 8 была выполнена оцифровка точечных, линейных и полигональных (площадных) объектов антропогенного происхождения. Для улучшения разрешающей способности спектральные каналы с разрешением 30 м синтезировали с панхроматическим каналом (15 м). Все работы по выявлению и оконтуриванию нарушенных участков проведены вручную, поскольку автоматическая и даже полуавтоматическая векторизация в условиях высокой мозаичности и мелкоконтурности тундровых ландшафтов неизбежно приводят к большим ошибкам. Регистрировали даже незначительные отклонения спектральных характеристик растительности от фоновых, относя их к соответствующему типу воздействий (например, вторичный растительный покров). Для идентификации типов техногенных нарушений использованы снимки спутников Sentinel-2A и Quick Bird, а также архивные данные и материалы, полученные в результате полевых работ в предыдущие годы (2001-2015 гг.).

\section{Результаты и обсуждение}

Фоновая оиенка биологического разнообразия и степень его изученности на территории Ненеикого автономного округа

Степень изученности модельных групп, очень разных по объему (от 2 до 760 видов) весьма неравномерна. Только по сосудистым растениям, птицам и млекопитающим, которые изучаются в округе уже более 200 лет, накоплен значительный материал, однако даже по ним информация из многих районов отсутствует.

Положение округа на границе между территориями европейского и сибирского, арктического и бореального биотических комплексов обусловливает сосуществование здесь видов с самыми разными типами ареалов.

Сосудистые растения (Tracheophyta). Богатство флоры НАО - 760 видов (у 26 из которых есть подвиды или разновидности). Сведения о видовом разнообразии имеются из 85 пунктов (от стационарных исследований до кратковременных посещений). Более или менее полно выявлены (но не все опубликованы) 48 локальных флор, из которых большинство изучены на п-ове Канин (Сергиенко, 2013), островах Колгуев и Вайгач, Югорском полуострове (Ребристая, 1977) и в Припечорских тундрах (восток Малоземельской и западная часть Большеземельской тундр). Слабо исследованными остаются труднодоступные районы Югорского п-ва, Тиманской, Малоземельской и Большеземельской тундр, куда можно добраться только вертолетом.

В арктических тундрах, которые представлены только в северной части о-ва Вайгач и на долю которых приходится лишь $0.5 \%$ площади НАО, исследована флора губы Долгая - 195 видов. В подзоне типичных тундр (23\% от площади НАО) изучены как островные, так и материковые локальные флоры. Они беднее в равнинных ландшафтах (на о-ве Колгуев в среднем 187 видов, на заболоченной низменности северо-востока Малоземельской тундры - 137), чем в тех, где на поверхность выходят горные породы (на о-ве Вайгач - 200, на Югорском полуострове - 175). В южных тундрах (48\% площади НАО) богатство локальных флор мало отличается в северной и южной полосах - в среднем, соответственно, 190 и 210 видов. В северной полосе лесотундры (18\% площади НАО) они включают в среднем около 240 видов, в южной $(11 \%)$ - в одной известной локальной флоре (Несь, п-ов Канин) выявлено 348 видов. Таким образом, явно выраженного тренда увеличения видового богатства с севера на юг от подзоны арктических тундр к северной лесотундре не наблюдается из-за разной представленности ландшафтов в подзонах. Высокое разнообразие локальной флоры в полосе южной лесотундры на п-ове Канин можно объяснить как наибольшей полнотой выявления (неоднократные посещения), так и разнообразием ландшафтов (приморские марши, песчаные дюны, пляжи, тундровые и лесные участки).

Половина флоры НАО представлена видами бореальной фракции (53\%). А доля видов арктической фракции, ареалы которых в равнинных районах не выходят за границы тундрового биома (т.е. собственно арктических, метарктических и арктоальпийских), составляет чуть меньше трети списка (28\%). По типам долготных ареалов лидируют циркумполярные и евразийские $-41 \%$ и $28 \%$, соответственно. Доля видов с европейскими ареалами - 15\%, «сибирскими» (здесь и далее по тексту: в широком смысле, с учетом азиатских и азиатскоамериканских) - 10\% (в локальных флорах о-ва Вайгач их чуть более $10 \%$, окрестностей Хайпудырской губы - 4.7\%, западнее р. Печоры $-<1-3.5 \%)$, амфиатлантическими и азиатско- 
американскими - по 1-5\%. При этом среди видов с европейскими ареалами, которые распространены преимущественно в западной части НАО (до р. Печоры), преобладают бореальные виды (61\%), арктических лишь 15\%. А среди видов с азиатскими ареалами, встречающихся преимущественно на востоке НАО (Вайгач и Югорский полуостров), напротив, бореальных видов лишь 18\%, а арктических - $49 \%$.

Недавно (Лавриненко и др., 2016) были проанализированы данные по составу, таксономической и географической структуре 18 локальных флор сосудистых растений островных (острова Долгий, Колгуев, Вайгач) и прибрежных (в пределах Малоземельской и Большеземельской тундр) территорий юго-восточной части Баренцева моря. Тринадцать из них выявлены и представлены впервые. Это значительно дополнило информацию о флоре относительно слабо изученной территориии НАО, для которой опубликовано менее 20 локальных флор, против около 200 в азиатской Арктике. Это также позволило уточнить некоторые фитогеографические рубежи: острова Долгий и Вайгач отнесены к Югорскому округу Урало-Новоземельской подпровинции, а о-в Колгуев - к Канино-Колгуевскому округу Канино-Печорской подпровинции Европейско-Западносибирской провинции Арктической области (Юрцев и др., 1978).

Мхи (Bryophyta) и печеночники (Marchantiophyta). По предварительным оценкам бриофлора НАО включает более 300 видов мхов и около 120 - печеночников. Сведения о мхах есть из 43 географических пунктов. Однако бо́льшая часть локальных бриофлор изучена на уровне «кратковременные посещения» и «проба флоры» и включает только широко распространенные и хорошо распознаваемые в природе виды, а также собранные при геоботанических описаниях. Целенаправленно (когда сборы осуществляли бриологи) в НАО мхи изучены лишь в бассейне р. Белой, на Тиманском Кряже (221 вид) (Железнова, Шубина, 2015) и на юго-западе о-ва Вайгач (165 видов, с учетом литературных данных - 191 таксон) (Железнова и др., 2007). Информация о печеночниках имеется всего из 12 пунктов НАО. Наибольшее число видов (53) приведено для Припечорских тундр (Константинова, Лавриненко, 2002), тогда как для севера Голарктики в целом известно 277 таксонов.

Лишайники (Lichenes). Богатство лихенофлоры НАО - 460 видов. Исследования про- ведены в 53 географических пунктах. Бо́льшая часть локальных лихенофлор изучена на уровне «кратковременных посещений» и «пробы флоры». И они включают только широко распространенные макролишайники (число видов редко превышает 100). Целенаправленная инвентаризация выполнена на острове Долгий в Баренцевом море - 252 вида макро- и микролишайников (Урбанавичюс и др., 2009). Ее можно рассматривать в качестве примера (модели) для типичных тундр европейского сектора Арктики. Наиболее полно лихенологическими исследованиями охвачены также острова Колгуев и Вайгач (окрестности бухты Лямчина) и территория Припечорских тундр.

Информация по разным модельным группам беспозвоночных животных НАО сильно варьирует по полноте. Из членистоногих относительно хорошо изучены только пауки и дневные чешуекрылые.

Дожндевые черви (Oligochaeta, Lumbricidae). Несмотря на обширность сборов (30 пунктов) и длительный период изучения (с 1875 г.), на территории НАО обнаружено только два вида дождевых червей-Dendrobaena octaedra (Savigny, 1826) и Eisenia nordenskioldi nordenskioldi (Eisen, 1879) с космополитным и преимущественно сибирским ареалами соответственно. Они отмечены во многих районах материковых и островных тундр Евразии (Перель, 1979; Bсеволодова-Перель, 1988). Эти виды Lumbricidae способны переносить замерзание не только в фазе кокона, но и в стадии червя. Это способствует успешности их экспансии на север (Мещерякова, Берман, 2014).

Клещи (Arachnida, Acari). Современный этап изучения акарофауны НАО можно считать первичным, несмотря на то, что сведения о клещах появились уже во второй половине XIX в. 1879 г. (Koch, 1879). Данные имеются из 24 географических пунктов НАО. Но только одна конкретная акарофауна (остров Долгий) выявлена относительно полно с 127 видами (Макарова, 2012). Из остальных пунктов известно от 1 до 79 видов, что никак не отражает их реальный объем. Общее число видов свободноживущих наземных клещей в НАО более 290. Однако, принимая во внимание практически неизученные таежные районы, можно ожидать, что, после тщательных исследований, оно возрастет в 1.5 раза. Для 22 видов гамазовых клещей по территории НАО проходит восточная или западная границы ареала. Для 41 вида (арктиче- 
ские, арктомонтанные, арктобореальные) здесь проходит южная граница их ареалов. Арктическая фракция по-разному выражена в фауне ведущих отрядов клещей. У гамазовых клещей доля арктических и арктомонтанных видов составляет 42\%. А среди широко распространенных в целом панцирных клещей такие виды единичны (4\%). Хорошо известна значительно бо́льшая специализация арктической фауны гамазовых клещей по сравнению с панцирными (Makarova \& Böcher, 2009; Makarova, 2015).

Пауки (Arachnida, Aranei). На территории НАО пауки известны из 22 пунктов, равномерно распределенных по всей материковой части и на островах Колгуев, Долгий и Вайгач. Аранеофауна НАО хорошо изучена и довольно богата (233 вида), что составляет 91\% всей фауны пауков тундр Европейской равнины (256 видов). В зональном отношении она является гипоарктической с преобладанием бореальных видов и незначительным участием (9\%) комплекса арктических элементов. В региональном отношении это - европейская фауна с высокой долей (20\%) «сибирских» видов. Самыми многочисленными являются бореальная, температная и полизональная группы (46, 68 и 52 вида, соответственно), вместе составляющие бо́льшую часть всей фауны. Арктические, арктобореальные и арктоальпийские виды немногочисленны, причем собственно арктических лишь 3.5\%. В восточной части округа более половины видов - «сибирские» (Tanasevitch \& Khruleva, 2017). У части таких видов западная область распространения ограничена лишь востоком Большеземельской тундры. Другие же проникают на запад вплоть до р. Печора. А некоторые, преодолев «печорский рубеж», достигают западных границ Малоземельской тундры и даже п-ова Канин. При этом р. Печора является восточным пределом распространения всего одного европейского вида - Oryphantes angulatus (O. Pickard-Cambridge, 1881).

Ногохвостки (Hexapoda, Collembola). Сведения о ногохвостках имеются из 28 пунктов, достаточно равномерно распределенных по территории НАО. Они касаются как самых западных (п-ов Канин), так и самых восточных (острова Вайгач и Долгий), но лишь прибрежных, районов. Данных из материковой части почти нет. Достоверно зарегистрировано 192 вида ногохвосток (Babenko et al., 2017). Большинство представителей обычны на севере Го- ларктики. По широтно-зональной приуроченности, к арктической фракции можно отнести около 10\% видов. По составу долготных ареалогических групп она является «смешанной»: ядро составляют широкоареальные виды (космополитные, голарктические и палеарктические). Доля видов с «сибирскими» ареалами - около 30\%. При этом сибирское «влияние» не ограничено только восточными районами (острова Вайгач или Долгий), но заметно и много западнее, в частности на о-ве Колгуев и даже на п-ове Канин.

Клопь (Insecta, Heteroptera). Фауна клопов НАО изучена довольно хорошо (48 видов), но неравномерно. Данные имеются из 18 локалитетов, расположенных преимущественно в Малоземельской и Большеземельской тундрах. Информация о структуре населения и особенностях биотопического распределения есть только для о-ва Долгий в Баренцевом море (Макарова, Макаров, 2006) и окрестностей Харбейских озер в Большеземельской тундре (Зиновьева, 2013). По составу ареалогических групп преобладают палеарктические $(50 \%)$ и голарктические виды $(42 \%)$. По широтной приуроченности большинство клопов относятся к арктотемператной группе. Типично тундровым является только Calacanthia trybomi (Sahlberg, 1878).

Жуки (Insecta, Coleoptera). Сведения о колеоптерофауне имеются из 39 географических пунктов НАО. Наибольшее число локалитетов расположено на п-ове Канин и в Большеземельской тундре. Всего на сегодняшний день известно 342 вида наземных и водных жуков. Первые изучены значительно лучше, нежели вторые. На широтном градиенте отмечена тенденция уменьшения видового богатства в локальных фаунах - от 83 видов в лесотундре до 23 видов в арктических тундрах. Ареалогический анализ колеоптерофауны показывает, что она сравнительно мало специфична и слагается из обычных широко распространенных видов. В ее составе преобладают голаркты и палеаркты с арктобореальным, бореальным и полизональным широтным распространением. Арктическими являются 12\% жуков. Для арктических и типичных тундр характерно повышенное присутствие видов с арктическим, арктомонтанным и арктобореомонтанным ареалами. При продвижении к югу видовое богатство колеоптерофауны в южных тундрах и лесотундре постепенно возрастает за счет полизональных и бореальных видов, что показано на жужели- 
цах (Колесникова и др., 2017). На примере жуков проявляется общее правило соотношения широтно-зональных фаунистических потоков. Так, бореальные и полизональные виды гораздо интенсивнее проникают в высокоширотные ландшафты, чем арктические на юг (Чернов, 1984). В долготном отношении колеоптерофауну НАО можно охарактеризовать как переходную между европейским и сибирским типами арктических фаун. Ее основу составляют трансголарктическая, транспалеарктическая и западнопалеарктическая долготные группы (вместе 85\%). Доли «сибирских» (9\%) и европейских (10\%) видов почти равны.

Двукрылые (Insecta, Diptera). Видовые списки двукрылых известны из 41 географического пункта НАО. Всего выявлено 569 видов. Фауна изучена неоднородно и по числу указанных видов (от 1 до 117 видов в локалитете), и по распространению на территории округа. Так, больше всего локалитетов расположено в Малоземельской, Большеземельской тундрах и на Югорском полуострове. При ареалогическом анализе выделено 24 группы видов, объединенные в три комплекса: мультирегиональный $(\sim 10 \%)$, голарктический ( 40\%) и палеарктический ( 50\%). Типично арктическими являются $\sim 23 \%$ видов двукрылых. В восточной части округа обнаружены четыре вида урало-сибирской группы. Это Cheilosia balu Violovitsh, 1966; Empis hirsuta (Becker, 1915); Prosimulium tridentatum (Rubtsov, 1940); Rhamphomyia armipes (Sack, 1923), основной ареал которых располагается в Сибири.

Дневные чешуекрылые (Insecta, Lepidoptera, Rhopalocera). На территории НАО зарегистрировано 73 вида дневных, или булавоусых, чешуекрылых из шести семейств. Из них постоянно обитают 50-65 видов. Еще 10-15 образуют лишь временные популяции, псевдопопуляции, совершают регулярные миграции из соседних областей в летний период, известны по единичным находкам или характер их обитания здесь пока точно не установлен (Татаринов, 2016). Накопленные материалы и критический анализ литературных сведений позволяют обоснованно утверждать, что коренной состав дневных чешуекрылых в регионе выявлен практически полностью. Новых находок ожидается немного, оценочно не более 3-4 видов. Лепидоптерологические данные получены из 34 географических пунктов НАО. Количество видов в наиболее изученных локаль- ных фаунах колеблется от 12 (типичная тундра) до 37 (лесотундра и северная тайга). Слабо исследованными районами остаются Пай-Хой и Югорский полуостров, Тиманская и Малоземельская тундры. Дополнительные исследования требуются на п-ове Канин, о-вах Вайгач и Колгуев. Фауна булавоусых чешуекрылых НАО имеет ярко выраженные «нимфалоидные» черты: более половины видов принадлежат к двум близким семействам Nymphalidae (25 видов) и Satyridae (16 видов). К этим же семействам принадлежат и наиболее насыщенные видами роды: Clossiana Reuss, 1920 (10 видов) и Erebia Dalman, 1816 (9 видов). Самый низкий уровень видового богатства у семейств Papilionidae и Hesperiidae (по три вида в каждом). Основу ареалогической структуры образуют транспалеарктическая (25 видов) и трансголарктическая (21 вид) долготные группы. По типу широтного распространения более половины видов являются представителями различных субарктотемператных групп. Дифференциальную компоненту ареалогической структуры фауны образуют восточноевро-трансазиатские (четыре вида) и субголарктические (четыре вида) чешуекрылые, у которых по территории округа проходит западная граница распространения. Видов арктической фракции всего 15.

Шмели (Insecta, Hymenoptera, Apidae, Bombini). На территории НАО отмечен 21 вид шмелей (род Bombus Latreille, 1802). Сведения о находках шмелей есть из всех природных зон. Это 16 географических пунктов на территории Большеземельской и Малоземельской тундр, п-ова Канин, островов Колгуев, Долгий и Вайгач. В локальных фаунах от 1 до 14 (Несь, п-ов Канин) видов. По долготной составляющей ареала виды объединяются в три комплекса: мультирегиональный $(28.4 \%)$, голарктический $(23.8 \%)$ и палеарктический (47.8\%). Большинство видов имеют широкие ареалы, охватывающие несколько природных зон. Арктический элемент фауны представлен двумя палеарктическими видами - Bombus hyperboreus Schönherr, 1809 и В. pyrrhopygus Friese, 1902.

Птицы (Aves). Орнитофауна НАО представлена 234 видами, из них 149 гнездящихся. Поскольку многие виды залетные, то эти цифры регулярно обновляются. Из 18 отрядов семь (Podicipediformes, Procelleriiformes, Pelecaniformes, Ciconiiformes, Caprimulgiformes, Upupiformes и Apodiformes) представлены только залетными видами, все остальные - в том 
числе гнездящимися. Наиболее разнообразны представители отрядов Passeriformes (76 видов), Charadriiformes (61 вид) и Anseriformes (38 видов).

Основу гнездовой фауны региона $(29 \%)$ составляют арктические, часто циркумполярные виды, в том числе типичные тундровые и виды открытых пространств (по Штегман, 1938). В состав орнитофауны входят $24 \%$ сибирских, $14 \%$ европейских и $26 \%$ широко распространенных видов. К настоящему времени на материковой части НАО наиболее полно изучена орнитофауна Большеземельской (Минеев, Минеев, 2012) и Малоземельской тундр (Минеев, Минеев, 2009), а также дельты р. Печоры. Особенно хорошо обследованы в последнее десятилетие острова Колгуев (Морозов, Сыроечковский, 2004; Kruckenberg et al., 2012), Вайгач (Алейников и др., 2014) и Долгий (Ануфриев, 2006). Тем не менее, даже в Большеземельской тундре, где сосредоточены основные районы нефтегазодобычи, орнитологические исследования на протяжении последних десятилетий были локальны и практически всегда охватывали лишь небольшие участки побережья Баренцева моря и районы по долинам нескольких крупных рек. В целом, авифауна НАО гетерогенна. И ее, согласно представлениям Кищинского (1988), подразделяют на зональные фаунистические комплексы: эоарктический, гемиарктический, гипобореальный, бореальный и небольшую группу - представителей других фаунистических комплексов.

Млекопитающие (Mammalia). На территории НАО обитает 33 вида наземных млекопитающих (Ануфриев и др., 1994; Полежаев и др., 1998; Ануфриев, 2004). Из них в количественном отношении наиболее представлены отряды Rodentia (14 видов) и Carnivora (10 видов). B материковых тундрах видовое разнообразие животных закономерно увеличивается с севера на юг - с 22 до 28 видов. Это связано с проникновением в южные районы тундр видов из таежной зоны (Talpa europaea Linnaeus, 1758, Sorex araneus Linnaeus, 1758, Sciurus vulgaris (Linnaeus, 1758), Clethrionomys glareolus (Schreber, 1980), Sicista betulina Pallas, 1779, Mustela nivalis Linnaeus, 1766). На островах Баренцева моря (Колгуев, Долгий и Вайгач) отмечено девять видов наземных млекопитающих, и лишь два из них - Alopex lagopus (Linnaeus, 1758) и Ursus maritimus Phipps, 1774 (заходы) известны на всех островах. На о-ве Колгуев, помимо двух этих видов, отмечен еще только Vulpes vulpes Linnaeus, 1758, а на о-ве Долгий Lepus timidus (Linnaeus, 1758). Отсутствие мелких млекопитающих на о-вах Колгуев и Долгий, по нашему мнению, является следствием неблагоприятных для этих видов погодных условий зимнего периода. Также вероятно и то, что широкие морские проливы, отделяющие о-ва Колгуев и Долгий от материка, соответственно, 70 км и 15 км, препятствуют заселению этих островов мелкими млекопитающими. Больше всего видов (восемь), включая мелких грызунов (Dicrostonix torquatus Pallas, 1778, Lemmus sibiricus (Kerr, 1792), Microtus gregalis (Pallas, 1779)) зарегистрировано на о-ве Вайгач, который отделен от материка узким (3 км) ежегодно замерзающим проливом. Считается, что в настоящее время постоянное население оленей на островах Колгуев и Вайгач представлено только домашней формой (Mizin et al., 2018).

Териофауна НАО включает шесть арктических видов (или $18 \%$ от общего числа), 16 - бореальных (48\%) и 11 - полизональных (33\%). Типично арктическими и субарктическими видами являются Dicrostonix torquatus, Lemmus sibiricus, Microtus middendorffi (Poliakov, 1881), Alopex lagopus, Ursus maritimus и новоземельский северный олень (Rangifer tarandus pearsoni Lydekker, 1903), который зимой совершает нерегулярные заходы на о-в Вайгач. Все остальные относятся к лесным (бореальным) или широко распространенным (полизональным) видам, обитающим здесь на северных границах своих ареалов. Доля видов с европейскими ареалами закономерно уменьшается к северу. Так, население мышевидных грызунов типичных тундр представлено только видами сибирского фаунистического комплекса: Dicrostonix torquatus, Lemmus sibiricus, Myodes rutilus (Pallas, 1779), Microtus gregalis, M. middendorffi. Во всей териофауне НАО доля «сибирских» видов составляет 18\%.

Анализ данных по распространению в округе 3675 видов растений и животных из 15 модельных групп организмов позволил выявить некоторые общие черты биоты НАO. Таксономическое разнообразие флоры и фауны округа составляет существенную часть видового богатства Арктики в целом (Hofgaard et al., 2012; Meltofte, 2013). Этот показатель не ниже, а по некоторым группам животных выше, чем в относительно хорошо изученных арктических регионах, сопоставимых по площади и уровню 
ландшафтного разнообразия, таких, например, как п-ов Таймыр и Гренландия.

На территории НАО к арктической фракции относится около 15\% видов модельных групп. Этот показатель варьирует от 0-2\% у дождевых червей и полужесткокрылых насекомых до 28-29\% у сосудистых растений и птиц (табл.). На широтном градиенте перестройки фауны особенно резки в мало характерной для Арктики группе полужесткокрылых насекомых (клопов) и слабо заметны среди почвенных ногохвосток. Это позволяет предполагать существенную преадаптацию этого таксона к условиям высоких широт в целом.

«Сибирский», европейский и широкоарельный географические элементы имеются в большинстве изученных групп организмов. У сосудистых растений в отдельных локальных флорах НАО доля видов с европейскими и «сибирскими» ареалами значительно уступает таковой с циркумполярными и евразиатскими. Число «сибирских» видов закономерно уменьшается к западу, a европейских - к востоку. Большинство видов с европейскими и амфиатлантическими ареалами распространены на восток вплоть до Югорского полуострова и Урала, лишь некоторые (например, Aconitum septentrionale Koelle, Arabis alpina L., Diapensia lapponica L., Erigeron borealis (Vierh.) Simm., Harrimanella hypnoides (L.) Cov., Veronica alpina L.) заходят и на север Западной Сибири. Ареалы части «сибирских» видов (Minuartia stricta (Sw.) Hiern, Poa supina Schrad.) ограничены назападе дельтой р. Печоры, другие же (например,
Achoriphragma nudicaule (L.) Soják, Alnus fruticosa Rupr., Artemisia tilesii Ledeb., Cotoneaster uniflorus Bunge, Geranium albiflorum Ledeb., Lagotis minor (Willd.) Standl., Pleurospermum uralense Hoffm., Rumex arcticus Trautv., Stellaria peduncularis Bunge) встречаются в Малоземельской и даже Канинской тундрах, хотя большинство (например, Arnica iljinii (Maquire) Iljin, Artemisia borealis Pall., Caltha arctica R. Br., Carex fuscidula V. Krecz. ex Egor., Cassiope tetragona (L.) D. Don., Pedicularis amoena Adam ex Stev., Tephroseris atropurpurea (Ledeb.) Holub) ограничены в распространении восточной частью Большеземельской тундры.

В составе модельных групп животных известно около 220 (чуть более 10\%) «сибирских» видов. Больше всего их среди ногохвосток, птиц и пауков (табл.). В конце XIX в. это явление стало поводом для Seebohm (1880) назвать книгу о птицах бассейна p. Печора «Siberia in Europe». Но среди такой относительно хорошо изученной группы, как шмели (21 вид в НАО) таких видов нет. А среди двукрылых насекомых «сибирских» видов всего около 1\%.

На территории НАО доля видов с европейскими ареалами к северу закономерно уменьшается, что отмечено во всех изученных группах. Это вполне объяснимо, поскольку западная часть округа, где доля европейских видов выше, расположена в подзонах от южных тундр до северной тайги. А выдвинутая к северу восточная часть региона занята только тундровыми ландшафтами, где особенно заметно участие «сибирских» видов.

Таблица. Таксономическое разнообразие модельных групп организмов на территории Ненецкого автономного округа Table. Taxonomical diversity of biotic model groups in the Nenetsky Autonomous Okrug

\begin{tabular}{|c|c|c|c|c|c|}
\hline \multirow{2}{*}{ Модельная группа } & \multicolumn{2}{|l|}{ Число } & \multicolumn{2}{|c|}{ Доля видов, в \% } & \multirow{2}{*}{$\begin{array}{c}\text { Наиболее разнообразные } \\
\text { семейства/отряды }^{2}\end{array}$} \\
\hline & пунктов изучения & видов & арктических ${ }^{1}$ & «сибирских»" & \\
\hline $\begin{array}{l}\text { Сосудистые растения (семен- } \\
\text { ные и папоротникообразные) }\end{array}$ & 85 & 760 & 28 & 10 & Poaceae, Asteraceae, Cyperaceae \\
\hline Лишайники & 53 & 460 & $?$ & $?$ & Parmeliaceae, Cladoniaceae, Lecanoraceae \\
\hline Мхи & 43 & $>300$ & $?$ & $?$ & Bryaceae, Sphagnaceae, Dicranaceae \\
\hline Печеночники & 12 & $\sim 120$ & $?$ & $?$ & Lophoziaceae, Scapaniaceae, Cephaloziaceae \\
\hline Дождевые черви & 30 & 2 & - & - & Lumbricidae \\
\hline Клещи & 23 & $>290$ & $\sim 23^{3}$ & $\sim 6$ & Ascidae, Zerconidae, Ceratozetidae \\
\hline Пауки & 22 & 233 & 9 & 20 & Linyphiidae, Lycosidae \\
\hline Ногохвостки & 28 & 192 & $\sim 10$ & $\sim 30$ & $\begin{array}{l}\text { Isotomidae, Hypogastruridae, Neanuridae, } \\
\text { Onychiuridae }\end{array}$ \\
\hline Клопы & 18 & 48 & 2 & 2 & Miridae \\
\hline Жуки & 39 & 342 & 12 & 9 & $\begin{array}{l}\text { Carabidae, Staphylinidae, Dytiscidae, } \\
\text { Chrysomelidae }\end{array}$ \\
\hline Двукрылые & 41 & 569 & $\sim 23$ & $\sim 1$ & Chironomidae \\
\hline Дневные бабочки & 34 & 73 & 20 & 11 & Nympalidae, Satyridae, Lycaenidae \\
\hline Шмели & 16 & 21 & 10 & - & Apidae \\
\hline Птицы & -4 & $\begin{array}{c}234 \\
(149)^{5} \\
\end{array}$ & 29 & 24 & $\begin{array}{l}\text { Passeriformes, Charadriiformes, } \\
\text { Anseriformes }\end{array}$ \\
\hline Млекопитающие наземные & 27 & 33 & 18 & 18 & Rodentia, Carnivora, Lipotyphla \\
\hline
\end{tabular}

Примечание: ${ }^{1}$ - в широком смысле; ${ }^{2}$ - для растений и беспозвоночных животных - семейства, для позвоночных - отряды; ${ }^{3}-$ рассчитано только для относительно хорошо изученных подотрядов Mesostigmata и Oribatida; ${ }^{4}-$ при изучении птиц широко используются маршрутные учёты различной протяженности, поэтому число точек наблюдения не приводим; ${ }^{5}-$ из них гнездящихся. 
Наиболее исследованной в НАО до настоящего времени остается биота ландшафтов Большеземельской тундры и, особенно, дельты $\mathrm{p}$. Печора. Это во многом обусловлено активным изучением биоразнообразия на территории государственного природного заповедника «Ненецкий» и двух заказников (Ненецкий и Нижнепечорский), а также относительной доступностью района. За последние два десятилетия получены довольно полные сведения о позвоночных животных и растениях островов Баренцева моря (Колгуев, Долгий с прилежащими малыми островами, Вайгач). Значительного пополнения списков отдельных групп биоты видами бореального комплекса можно ожидать в ходе изучения лесотундровых и таежных районов округа. Детальные исследования в типичных и арктических тундрах несомненно пополнят фауну арктическими элементами «сибирской» фракции, но, очевидно, не столь существенно. Малоизученными остаются территории Тиманской тундры, п-ова Канин, Малоземельской тундры и Югорского полуострова.

Новые данные по растительным и животным объектам Ненецкого автономного округа

Не весь материал, собранный в ходе экспедиции 2015 г., обработан до конца к настоящему времени. Но уже сейчас по многим модельным группам организмов получены знания о новых видах и новых местонахождениях. Это еще раз подтвердило и неравномерность исследования территории округа, и слабую изученность многих групп организмов. Новые сведения получены не только по видам беспозвоночных животных, но и по позвоночным животным, сосудистым растениям и растительным сообществам.

В ходе экспедиции особое внимание было уделено приустьевым областям рек, впадающих в губы, где сформированы марши - плоский и хорошо увлажненный аккумулятивный ландшафт, формирующийся под действием приливов, волн и нагонов с отложением рыхлого илистого или песчаного материала (рис. 3).

Впервые в НАО были обнаружены и описаны сообщества с Carex salina Wahlenb. на побережье Болванской губы, слабосоленой из-за сильного опресняющего влияния р. Печоры, и в тыловых частях маршей Паханческой и Хайпудырской губ, также слабосоленых из-за влияния стока пресных вод с более высоких террас. На солоноватых маршах всех трех губ по мере удаления от слабосоленых водотоков описан эколого-динамический ряд сообществ с доми- нированием этого вида осоки. В их составе других галофитов (Calamagrostis deschampsioides Trin., Carex glareosa Wahlenb., C. mackenziei V. Krecz., Potentilla egedii Wormsk.) уже мало, и они не обильны. Так, на маршах низких и средних уровней описана ассоциация Stellario crassifoliae - Caricetum salinae Lavrinenko et Lavrinenko 2018 (против ассоциации Caricetum salinae Nordh. 1954 соленых маршей западноевропейской Арктики) с тремя субассоциациями inops, typicum и galietosum trifidi. На маршах высоких уровней выделены две новые субассоциации ассоциации Parnassio palustris - Salicetum reptantis Matveyeva et Lavrinenko ex Lavrinenko et Lavrinenko 2018: aulacomnietosum palustris и caricetosum salinae. Впервые на мелководьях Болванской губы описаны сообщества ассоциации Eleocharitetum palustris Savič 1926. На соленых маршах, низкие и средние уровни которых подвержены непосредственно влиянию морских приливов (первые - каждодневным, вторые - лишь сизигийным), а высокие - только нагонам воды, на побережьях Паханческой и Хайпудырской губ описан эколого-динамический ряд сообществ синтаксонов, аналогичных таковым, выделенным ранее в Малоземельской тундре на побережье Печорской и Колоколковой губ (Матвеева, Лавриненко, 2011). Это ассоциация Puccinellietum phryganodis Hadač 1946 с субассоциациями inops Hofmann 1969 и caricetosum subspathaceae Thannheiser et Willers ex Lavrinenko et Lavrinenko 2018; ассоциация Caricetum subspathaceae Hadač 1946 с субассоциациями inops Molenaar 1974 и arctanthemetosum hultenii Matveyeva et Lavrinenko 2011; ассоциация Caricetum glareosae Molenaar 1974 вик. Calamagrostis deschampsioides Matveyeva et Lavrinenko 2011 с субассоциациями typicum Molenaar 1974 и festucetosum rubrae Molenaar 1974; ассоциация Parnassio palustris - Salicetum reptantis субассоциация typicum Lavrinenko et Lavrinenko 2018; ассоциация Caricetum mackenziei Nordh. 1954; ассоциация Scirpeto - Hippuridetum tetraphyllae Nordh. 1954 субассоциация inops Matveyeva et Lavrinenko 2011. Впервые на соленых маршах описана субассоциация Caricetum glareosae agrostietosum stoloniferae Lavrinenko et Lavrinenko 2018 (с вариантами typica и Triglochin maritimum) (Лавриненко, Лавриненко, 2018).

Во время экспедиционных работ 2015 г. сделаны находки ряда видов сосудистых растений, значительно изменивших представление об их ареалах: 


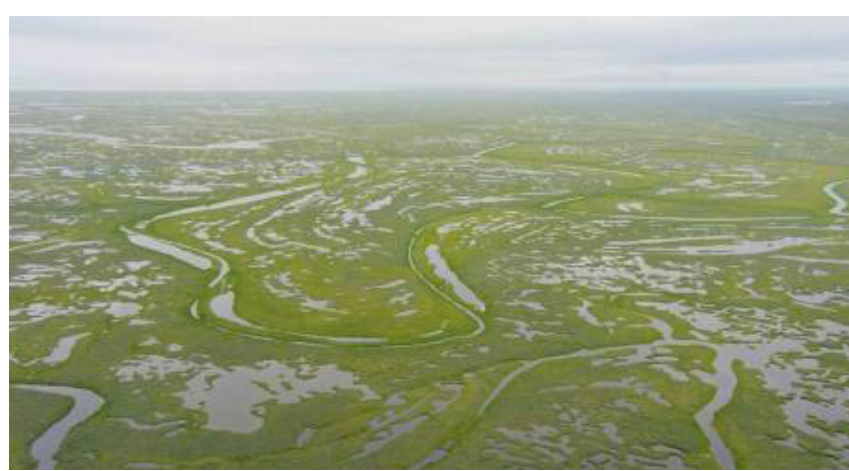

Рис. 3. Приморские марши Паханческой губы. Фото О.В. Лавриненко.

Fig. 3. Sea coastal marshes in Pakhancheskaya Bay. Photo: O.V. Lavrinenko.

Carex salina Wahlenb. - амфиатлантический вид, имеющий гибридное происхождение (Carex subspathacea $\times$ C. recta). Ранее восточную границу его распространения проводили по восточному побережью Белого моря (п-ов Канин). Упоминание Т.М. Королевой о находке Carex salina в районе Варандейской лапты стало основанием для включения его в Приложение к Красной книге Ненецкого автономного округа (2006). Мы обнаружили крупные популяции этого вида на солоноватых маршах Болванской, Паханческой и Хайпудырской губ.

Eleocharis palustris (L.) Roem et Schult. - широко распространенный в умеренном поясе Северного полушария вид, обычный в лесной зоне. Севернее границы лесотундры прежде не был найден. Находка на побережье Болванской губы (устье р. Ячей), где он образует заросли на мелководье, заметно «сдвигает» к северу границу его ареала.

Juncus gerardii Loisel. subsp. atrofuscus (Rupr.) Tolm. - преимущественно европейский подвид амфиатлантического вида, распространенный вдоль морских побережий Европы. Ранее восточную границу ареала вида проводили по р. Индиге. Местонахождения таксона в районе Хайпудырской губы, где он образует монодоминантные сообщества, являются самыми восточными из ныне известных на европейском севере.

Picea obovata Ledeb. представлена единичными молодыми деревьями, обнаруженными в устье р. Море-Ю, впадающей в Хайпудырскую губу. Эти местонахождения могут рассматриваться как свидетельство продвижения Picea obovata на север по поймам рек с «лесного острова Море-Ю», расположенного южнее.

Plantago maritima L. subsp. subpolaris (Andrejev) Tzvel. - крайние восточные точки apeaла этого подвида ранее фиксировали в Тиманской и Малоземельской тундре (Цвелев, 1983). Новые находки таксона отмечены значительно восточнее - в районах Паханческой и Хайпудырской губ.

Potamogeton filiformis L. - плюризональный амфиокеанический вид, включенный в глобальный Красный список МСОП. В НАО ранее был указан лишь для нижнего течения р. Печоры. Мы обнаружили заросли этого рдеста в мелководных водоемах на приморских маршах всех исследованных губ.

Salix pulchra Cham. - азиатско-американский вид. Обнаружен впервые в зональных сообществах в районе Паханческой губы, где растет вокруг пятен суглинка. Это самая западная находка, ранее был отмечен на хр. Пай-Хой и в бассейне р. Коротаиха, где нередок.

Triglochin maritimum L. впервые найден на маршах Паханческой губы. До этого вид был известен в округе только с Канино-Тиманского побережья Баренцева моря (на восток до р. Индига) и изолированно - из Хайпудырской губы.

Полевые работы и анализ коллекций позволили значительно пополнить знания по модельным группам животных и собрать обширные данные о населении приморских районов Большеземельской тундры с особым вниманием к сообществам маршей. Использование широкого спектра методов учета беспозвоночных и привлечение к их определению специалистов по группам позволили значительно уточнить сведения об их разнообразии в НАО.

Впервые для НАО обнаружен 201 вид беспозвоночных животных (в т. ч. 131 - насекомых). Это «расширило», в отдельных случаях на тысячи километров, ареалы многих видов. Представители типа волосатиков (Nematomorpha, род Gordius L., 1758) и семейства жуков Heteroceridae были впервые обнаружены в российской Арктике, а жуки-могильщики (Nicrophorus Fabricius, 1775) - в Арктике в целом. Четыре вида тлей и один род почвенных клещей (Rackia Mahunka, 1975) были впервые отмечены в России (Khaustov \& Makarova, 2016; Stekolshchikov, 2017). Найдено 17 новых для науки видов микроартропод, пять из них уже описаны (Khaustov \& Makarova, 2016; Babenko et al., 2017). Почти все виды двукрылых насекомых (56 из 63) и более 70 (из 165) видов жуков были впервые обнаружены на территории HAO (Prokin et al., 2017; Сорокина, 2017). Это увеличило общий объем фауны жуков округа на $20 \%$, а фауны приморских районов - на $33 \%$ (рис. 4). Впервые на территории Европы отмечены 29 видов беспозвоночных животных, чей 
основной ареал находится в сибирском, восточно-палеарктическом или сибиро-американском секторе Голарктики (пример на рис. 5).

Впервые на территории НАО проведены детальные количественные учеты почвенных микроартропод. Это позволило значительно увеличить число видов ногохвосток в НАО (со 152 до 192). Это больше, чем разнообразие группы в почвах Таймыра или Кольского полуострова (Babenko et al., 2017). Весьма высока и общая численность ногохвосток, как правило, 2000 3000 экз. / дм². Более 40 видов клещей впервые отмечено в НАО. Установленное видовое богатство почвенных клещей локальной фауны Матюй-Саля, Паханческая губа (142 вида) является рекордным для Арктики. Слабая топическая дифференцированность населения микроартропод сопровождается весьма высоким разнообразием ценотических фаун, существенно превышающим уровни, типичные для лесной зоны. Так, почву отдельных биотопов населяет по 40-65 видов клещей, и даже в отдельных пробах почвы $5 \times 5 \times 5$ см отмечено до 43 видов.

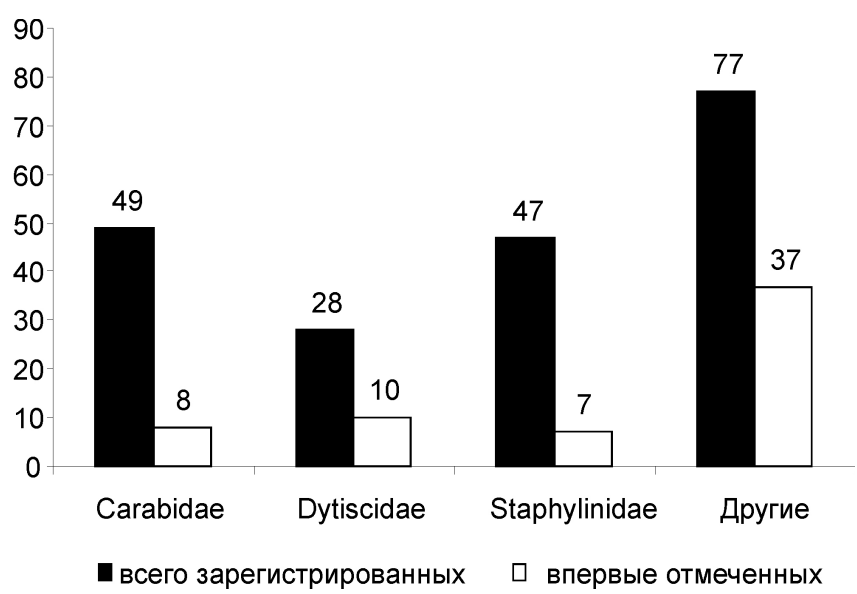

Рис. 4. Число видов жуков различных семейств в приморских районах Ненецкого автономного округа (всего и найденных впервые в 2015 г.).

Fig. 4. The number of beetle species from different families in total (black) and found for the first time in 2015 (white) in coastal areas of the Nenetsky Autonomous Okrug.

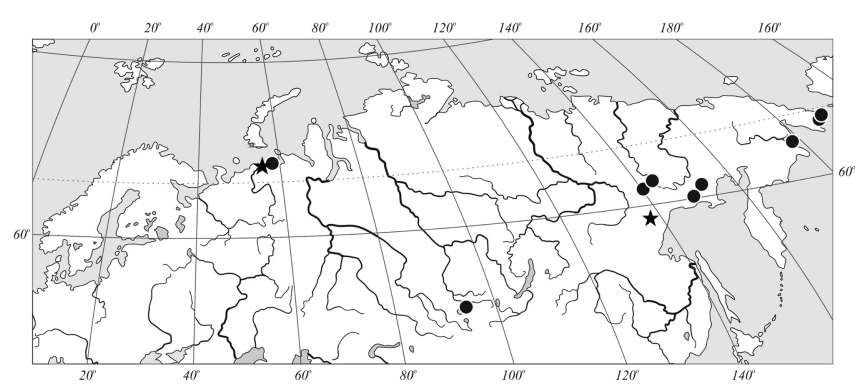

Рис. 5. Находки «сибирских» видов клещей. • - Zerconopsis sp., $\star$-Iphidozercon colliculatus Gwiazdowiczy et Marchenko, 2012.

Fig. 5. Records of «Siberian» mite species. - Zerconopsis sp., $\star-I p h i d o z e r c o n$ colliculatus Gwiazdowiczy et Marchenko, 2012.
Среди микроартропод, во всех трех районах полевых работ, около половины видов соответствующих локальных фаун встречалось на маршах. Таксономический состав в разных районах сходен (Dice Index 0.6-0.8). Фауна и население различных зон маршей весьма четко дифференцированы. Разнообразие и общая численность закономерно возрастают от нижних уровней к верхним. На низких маршах среди коллембол преобладают типичные литоральные формы, а среди клещей - обитатели литоралей и сырых лугов (Бизин, 2016). Население высоких маршей сходно с таковым в сырых тундрах.

При сравнении населения микроартропод разных уровней маршей, выборки распадаются на две основные группы (группировки нижних и верхних уровней) независимо от района работ (рис. 6). Таким образом, структура населения маршей определяется, в первую очередь, положением на профиле. Высокие марши населены наиболее сложными полидоминантными сообществами, где довольно разнообразно представлены малочисленные и редкие виды, обычные в прилегающих тундрах. Самые низкие уровни соленых маршей занимает специфическая группировка, сформированная немногими специализированными (литоральными и гидрофильными) видами, ее численность минимальна. Население микроартропод высоких уровней маршей значительно варьирует по районам, тогда как на низких - повсеместно обитает единый комплекс видов (рис. 6). В сообществах высоких уровней, в целом, сильнее выражена региональная специфика, что было показано для маршевых сообществ панцирных клещей Западной Европы (Weigmann, 2008).

Разнообразие пауков на маршах Баренцева моря довольно велико (18-20 видов в отдельных районах). Численность колеблется в пределах 6.4-150.4 экз./ $\mathrm{M}^{2}$. Ее минимальные значения отмечены на низких уровнях маршей, где обитает по 2-6 видов. Население специфично в сравнении с близлежащими тундровыми биотопами (кустарничково-моховыми и кустарничково-лишайниковыми тундрами, ерниками, ивняками). Но характерные виды единичны и малочисленны, а большинство - обитатели сырых лугов и различных болот.

В материалах экспедиции среди жуков (165 видов) наиболее разнообразно представлены семейства Carabidae (49 видов), Staphylinidae (47) и Dytiscidae (28), что характерно для apктических районов (Чернов и др., 2014). Сход- 
ство рассмотренных локальных фаун невысоко (коэффициент Жаккара для наземных жуков 30-40\%, для водных 39-52\%). Лишь 23 вида (14\%) водных жуков отмечены во всех районах работ (Prokin et al., 2017).

В исследованных водотоках и водоемах Большеземельской тундры было выявлено 16 видов моллюсков, в том числе Lymnaea dolgini Gundrizer et Starobogatov, 1979 (Беспалая и др., 2017). Этот вид широко распространен в Сибири и Западной Монголии (Vinarski et al., 2016) и ранее считался сибирским эндемиком. В бассейне р. Печоры зарегистрирован впервые.

Наши находки остромордой лягушки (Rana arvalis Nilsson, 1842) на побережье Болванской и Паханческой губ - самые северные на сегодняшний день в Большеземельской тундре (см. Кузьмин, 1999).

Летний состав орнитофауны маршей на побережье Большеземельской тундры в целом сходен с таковым низменных внутренних районов (Минеев, Минеев, 2009, 2012). В 2015 г. было зарегистировано 72 вида птиц: по 55 - в Болванской и Паханческой губах и 61 - в Хайпудырской. Преобладают типичные представители арктической орнитофауны, широкоареальные и «сибирские» виды (рис. 7). Во всех губах отмечены крупные скопления водоплавающих птиц и куликов. Например, общая численность водоплавающих птиц в Хайпудырской губе - около 140000 особей (Ануфриев, 2000). Большие количества на маршах линных и кочующих птиц привлекают, в свою очередь, множество редких хищных птиц, в первую очередь Falco peregrinus Tunstall, 1771 и Haliaeetus albicilla (Linnaeus, 1758). Особенно важны эти экотопы для гнездования Cygnus columbianus bewickii (Yarrel, 1830), численность которого в этих местообитаниях на порядки выше, чем в тундрах. На осенних остановках здесь могут скапливаться до 1000 особей. Сохранение маршевых экосистем имеет большое значение в качестве меры охраны редких внесенных в Красную книгу и мигрирующих видов птиц (van der Graaf et al., 2004).

Летом 2015 г. оценена плотность размещения выводковых нор Alopex lagopus, которая составила в районе Болванской губы - 1.2 норы на 10 км², Паханческой - 1.8 норы на 10 км²,

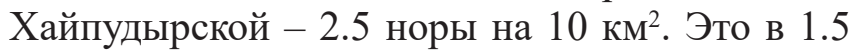
раза выше, чем отмечалось в тех же районах в 1980-1990-х гг. ХХ в. (Ануфриев, 2010).

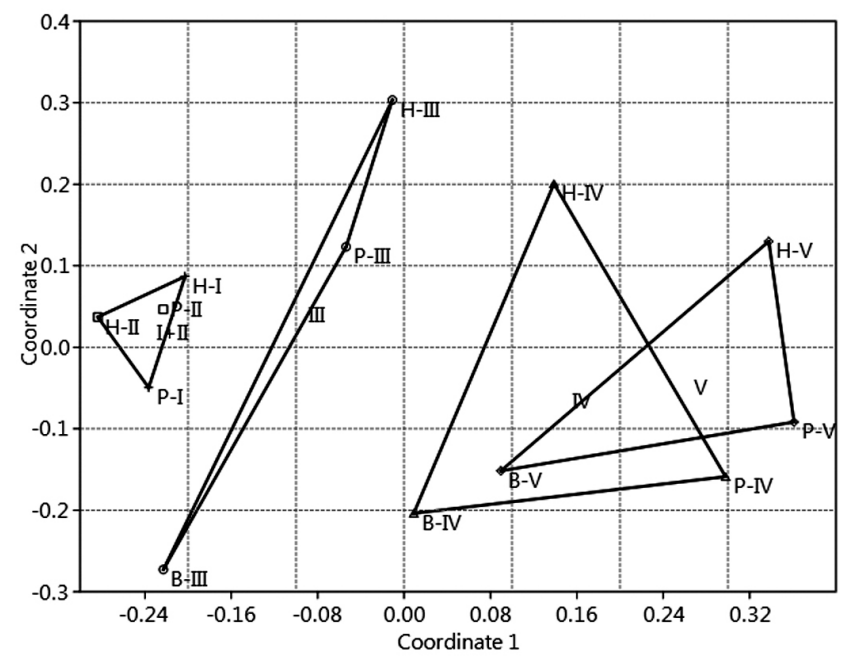

Рис. 6. Ординация сообществ гамазовых клещей на разных уровнях маршей по средним значениям численности видов в выборках (non-metric MDS. Similarity index: Rho, PAST 3.11). Губы: В - Болванская, P - Паханческая, H - Хайпудырская. Римские цифры соответствуют уровням маршей по нарастанию.

Fig. 6. Ordination of gamasid mite communities at different levels of marshes according to mean species numbers in samples (non-metric MDS. Similarity index: Rho, PAST 3.11). Designations: B - Bolvanskaya Bay, P - Pakhancheskaya Bay, $\mathrm{H}$ - Khaipudyrskaya Bay. Roman numbers indicate levels of marshes from low to high.

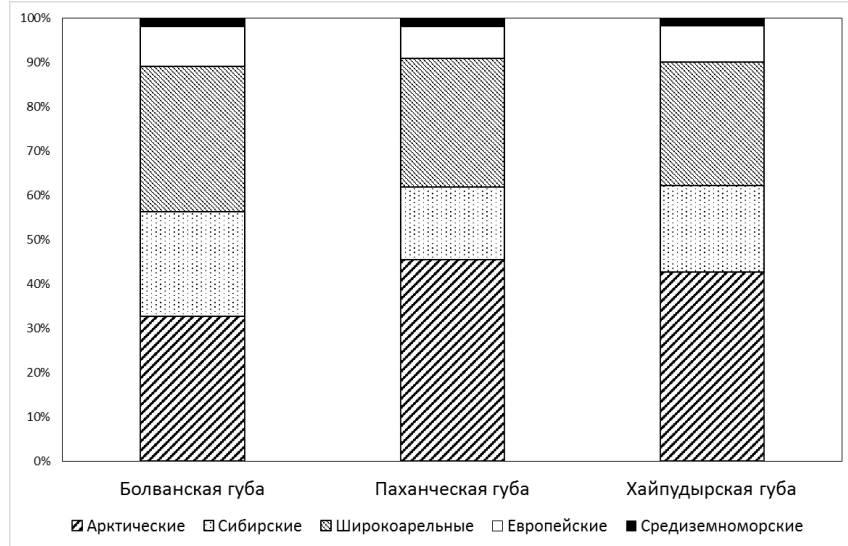

Рис. 7. Географическая структура (соотношение ареалогических групп видов, \%) населения птиц Болванской, Паханческой и Хайпудырской губ (по данным учетов 2015 г.).

Fig. 7. Geographical structure (ratio of range groups of species, \%) of the avifauna in the Bolvanskaya Bay, Pakhancheskaya Bay and Khaipudyrskaya Bay (according to records in 2015).

Дифферениированная оиенка биологической ценности территории Ненецкого автономного округа

Инвентаризация данных о биологическом разнообразии НАО позволила провести дифференцированную оценку отдельных пространственных выделов. В связи с обширными территориальными пробелами в изученности модельных групп принято решение о необходимости фор- 
мирования экспертных оценок распространения ключевых видов флоры и фауны на исследуемой территории. Основой для экстраполяции данных натурных наблюдений служит детальное геоботаническое районирование (Лавриненко, 2012б), учитывающее, помимо фитоценотического разнообразия, геоморфологические и почвенномерзлотные условия, а также распределение зеленой фитомассы (NDVI) (Raynolds et al., 2012). Ниже приведены примеры такого дифференцированного анализа территории по некоторым группам животных и редким сосудистым растениям.

В качестве основы для определения ценности геоботанических районов НАО в отношении биоразнообразия, проведена экспертная оценка видового богатства и распространения отдельных видов модельных групп по районам. Подходы к ранжированию районов в значительной степени индивидуальны для каждой модельной группы, и зависят в основном от особенностей биологии и экологии видов и группы в целом, конкретных способов учета и накопленной информации.

Так, для млекопитающих экспертная оценка формировалась по двум основным критериям. Район имеет более высокую ценность, если он:

- характеризуется высокими показателями обилия арктических видов (лемминги и песец); - является местом обитания видов млекопитающих, занесенных в Красную книгу Российской
Федерации (2001) (новоземельский северный олень) и Красную книгу Ненецкого автономного округа (2006) (дикий северный олень).

В отношении млекопитающих проведен экспертный анализ распространения всех 33 видов. Для каждого вида по 4-балльной шкале дана оценка его представленности (обилия / встречаемости) в каждом геоботаническом районе, на основе чего формировалась карта распространения вида (пример на рис. 8). Наименьшей ценностью обладают районы, территорию которых преимущественно населяют виды с широкими ареалами (полизональные, космополиты).

При оценке авифауны районов учтено также распространение 21 важного в биоресурсном отношении вида птиц.

Характеристика ценности орнитофауны проведена по целому комплексу показателей для следующих групп видов птиц, наиболее значимых для сохранения биоразнообразия региона при хозяйственном освоении и по которым есть наиболее полная информация:

- занесенные в Красную книгу Ненецкого автономного округа (2006) и Красную книгу Российский Федерации (2001);

- охотничье-промысловые (в т.ч. водоплавающие и околоводные);

- хищные, специально не охраняемые.

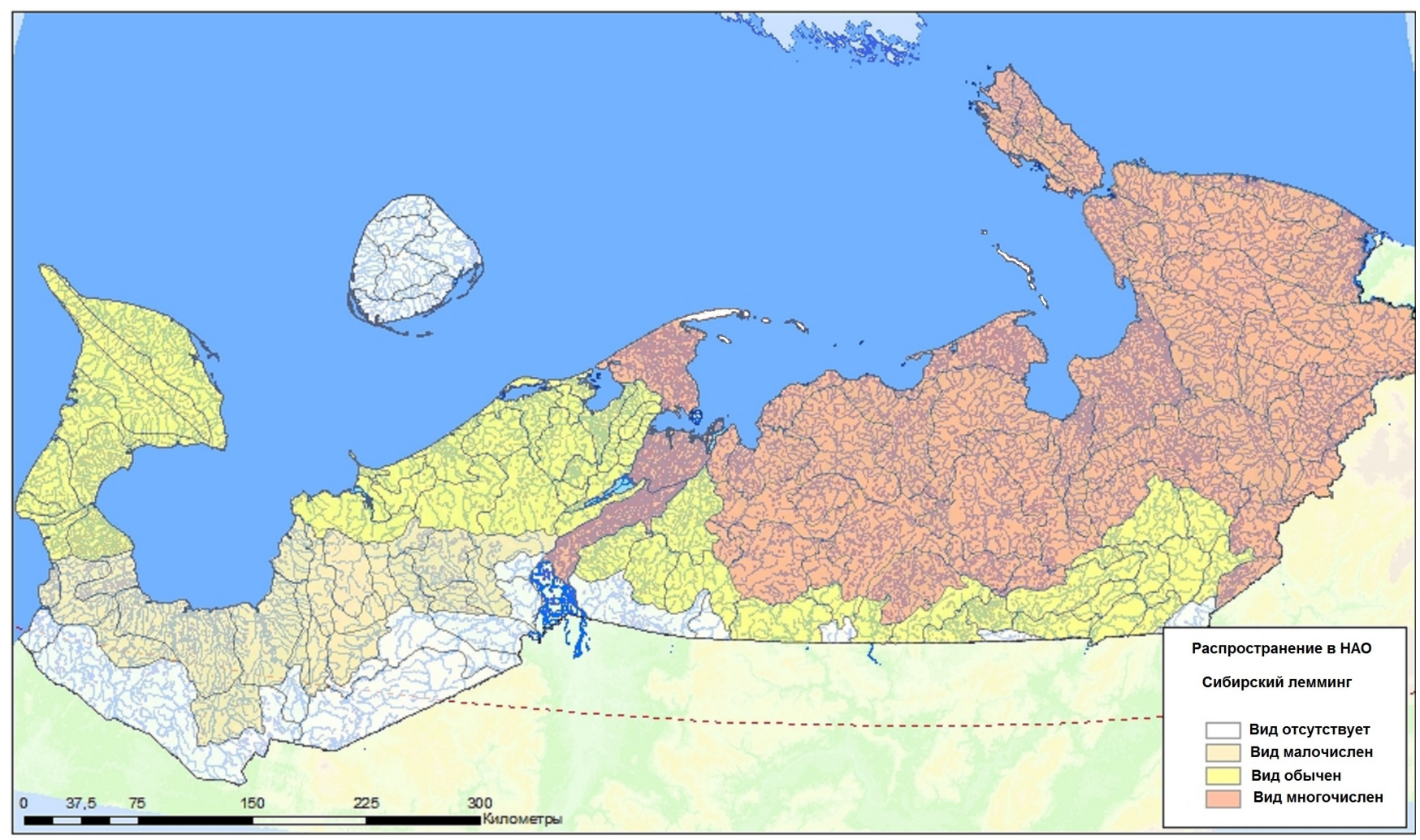

Рис. 8. Карта-схема - пример экспертной оценки распространения видов млекопитающих (Lemmus sibiricus).

Fig. 8. The map - an example of expert assessment of a mammal's (Lemmus sibiricus) distribution. 
Для птиц характерна сложная структура ареала, которая состоит из районов гнездования и зимовок, путей миграции. Учитывались важные места линных скоплений, концентрации на путях миграций и кочевках, места вождения выводков, кормовые местообитания. Оценивали не только таксономическое разнообразие в районе гнездящихся видов указанных групп, но и разнообразие местообитаний, в т.ч. ключевых территорий для других периодов их жизненного цикла. Принимали во внимание также наличие ценных местообитаний, таких как марши, водно-болотные угодья и ключевые орнитологические территории. «Орнитологическую ценность» района оценивали для каждой группы по 4-балльной шкале по возрастанию: где «0» - район не представлен в данный момент видами группы, либо данные местообитания не важны для группы; «1»- малоценный; «2» - ценный; «3» - весьма ценный. Общий показатель для района определяли суммированием этих значений с последующим ранжированием (рис. 9). В итоге, биологическая ценность отдельных районов НАО на материале птиц была оценена как невысокая, средняя или высокая. Статус наиболее ценных получили районы прибрежных и островных экосистем, являющихся экотонами между морем и сушей, привлекающими как морских, так и многих пролетных птиц.

Для менее изученных беспозвоночных животных критерии оценки были упрощены, что связано с небольшим объемом материалов по группе. Так по шмелям использована в основном оценка их видового богатства (числа видов) в данном геоботаническом районе и присутствие уникальных видов. В меньшей степени учитывали известные закономерности влияния климатических и орографических факторов.

При присвоении балла ценности районам по населению дневных бабочек использованы следующие критерии:

- число зарегистрированных в конкретном районе видов, занесенных в Красные книги, и, соответственно, их доля (\%) от всего списка таксонов, внесенных в Красные книги, в НАО;

- численность и характер встречаемости в районе локальных популяций видов, внесенных в Красные книги.

Проведен детальный количественный анализ распространения и обеспеченности охраной редких видов сосудистых растений, которые могут служить хорошим показателем природоохранной значимости изучаемых территорий. Это связано как с их более полной изученностью по сравнению с другими группами организмов, так и с наличием обширных описательных и картографических материалов по локализации видов, полученных за более чем столетний период. Для оценки природоохранной значимости геоботанических районов использованы данные о разнообразии и встречаемости редких видов сосудистых растений, включенных в Красные книги Ненецкого автономного округа (2006) и Российской Федерации (2008), как наиболее чувствительных к изменениям среды и уязвимых.

В Красную книгу Ненецкого автономного округа (2006) включено 102 вида сосудистых растений, для которых в пределах округа зарегистрировано более 1300 местонахождений (рис. 10).

Для объективной оценки природоохранной значимости каждого геоботанического района были рассчитаны следующие четыре показателя: 1 и 2 - число охраняемых видов сосудистых растений и число их регистраций, независимо от видовой принадлежности, в пределах геоботанического района; 3 и 4 - относительные (на 10 км²) показатели плотности охраняемых видов и плотности их находок в пределах геоботанического района. Наибольшие значения показателей 1 и 2 отмечены для геоботанических районов на островах Вайгач и Долгий и низкогорьях хр. Пай-Хой. Поскольку показатели 3 и 4 зависят от площади, то картина распределения видов по районам изменилась. Наибольшее относительное число видов

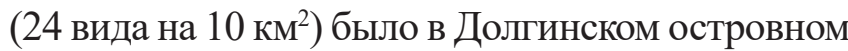
районе (о-в Долгий и прилегающие малые острова). И оно более, чем в три раза, превышает таковое для ближайшего Талата-Юнояхского района

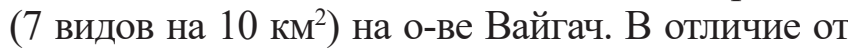
абсолютных показателей, это лучше отражает реальное положение. Так, близкие числа видов (28 и 34 соответственно) на островах Долгинского района (114.6 км²) и в пределах Талата-Юнояхского района на в четыре раза большей площади $\left(470.8\right.$ км$\left.^{2}\right)$. Высокие показатели относительной плотности охраняемых видов отмечены и в дру-

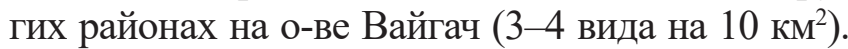
За ними следуют материковые районы Святоносский и Устьиндигский (2-3 вида на 10 км²). Относительная плотность находок максимальна также для Долгинского островного района (54 находки

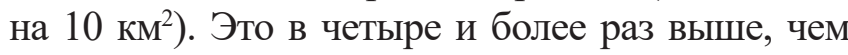
для Талата-Юнояхского и Сармик-Лангаседского (по 12 находок) районов на о-ве Вайгач. В группе с высоким значением показателя 4 находятся и другие геоботанические районы о-ва Вайгач и хр. Пай-Хой. Для получения интегральной оцен- 
ки числа и встречаемости охраняемых видов сосудистых растений в геоботаническом районе значения каждого из четырех показателей были ранжированы и переведены в баллы, которые затем суммировали. Максимальное значение (20 баллов) характерно для Долгинского геоботани- ческого района. Далее следуют районы о-ва Вайгач и хр. Пай-Хой (19-11 баллов) (рис. 11). Для 26 районов величины показателя 5 составили от 10 до 6 баллов, а более чем для половины районов, где охраняемые виды сосудистых растений обнаружены, - 5 и менее баллов.

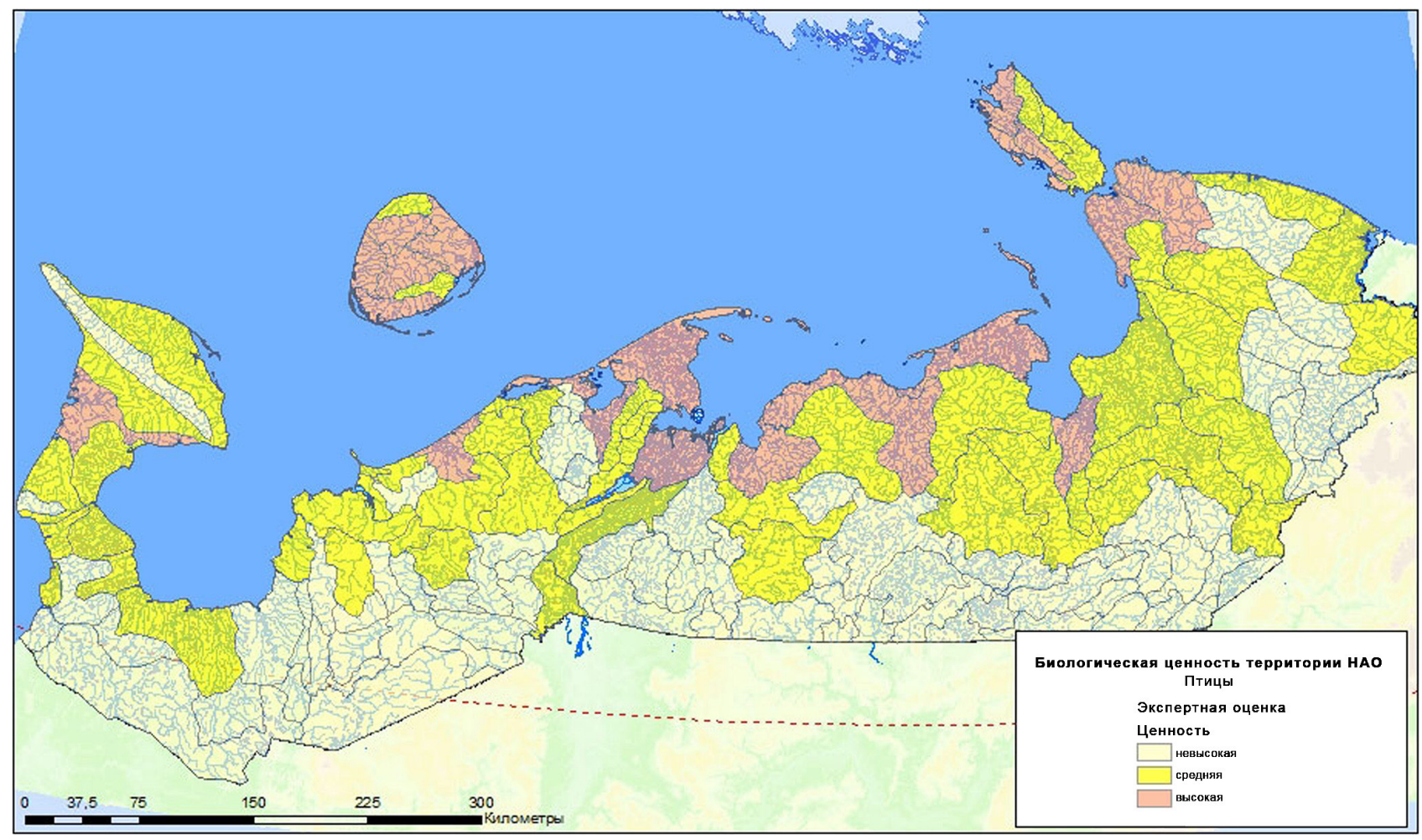

Рис. 9. Карта-схема экспертной оценки уровня биологической ценности геоботанических районов по птицам.

Fig. 9. The map of expert assessment of the biological value of geobotanical districts based on bird data.

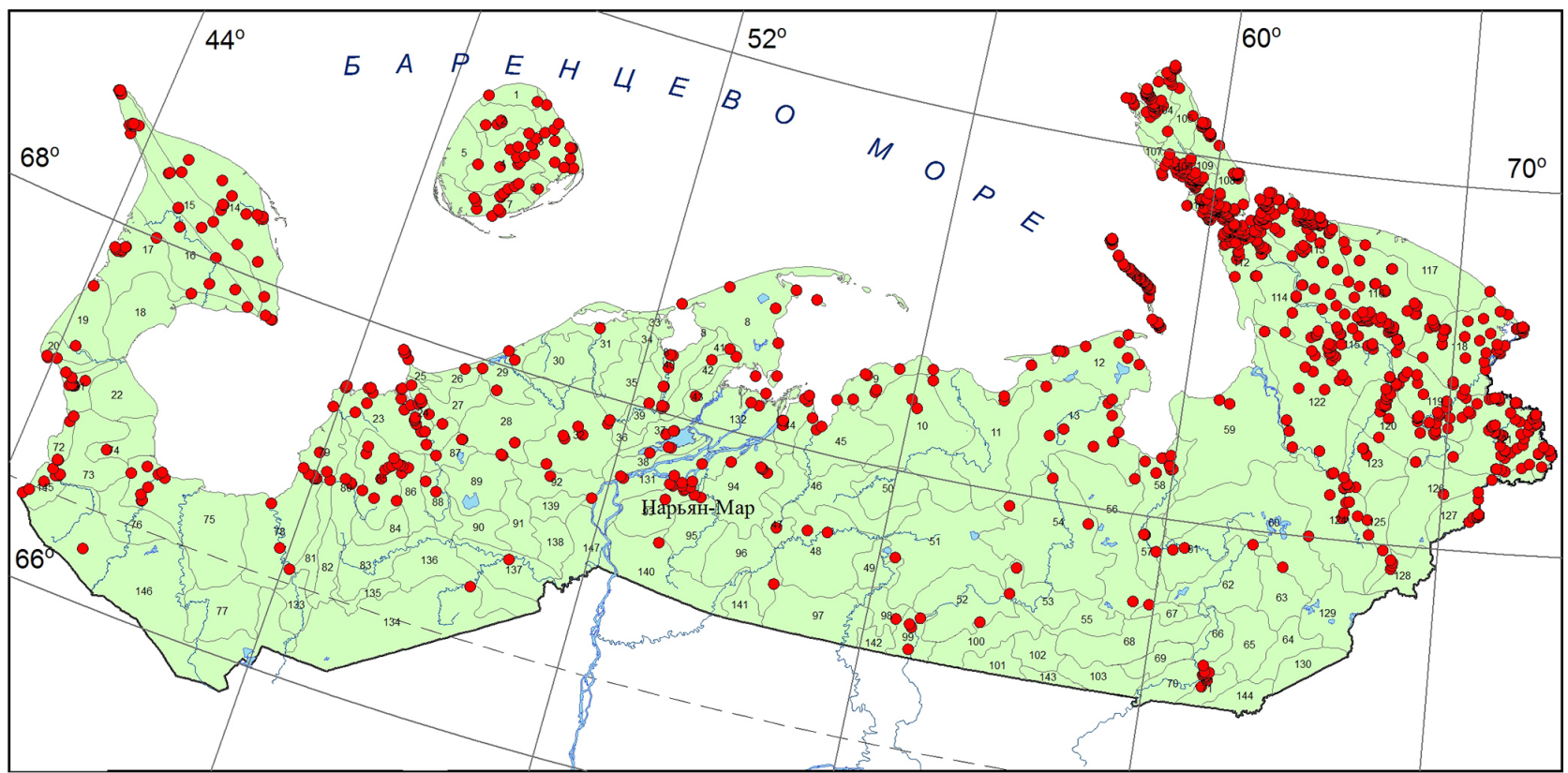

\section{Условные обозначения}

124 номер геоботанического района

Распределение находок видов сосудистых растений Красных книг НАО и РФ в геоботанических районах НАО

- находки видов Красных книг (более 1300)

Рис. 10. Местонахождения видов сосудистых растений, включенных в Красные книги Ненецкого автономного округа (2006) и Российской Федерации (2008).

Fig. 10. Locations of vascular plant species included in the Red Data Book of the Nenetsky Autonomous Okrug (2006) and in the Red Data Book of the Russian Federation (2008). 


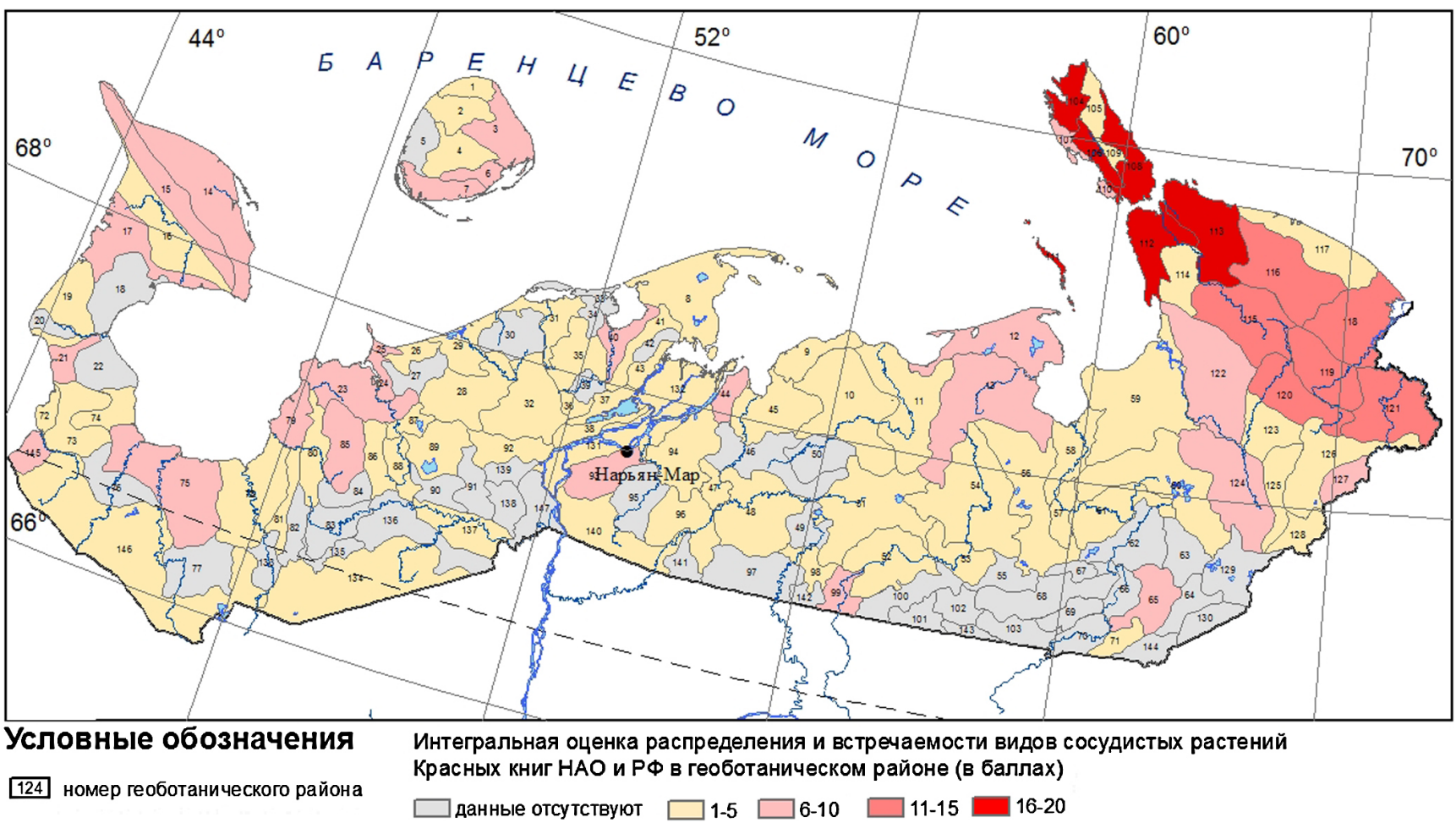

Рис. 11. Интегральная оценка числа и встречаемости видов сосудистых растений, включенных в Красную книгу Ненецкого автономного округа (2006) и Красную книгу Российской Федерации (2008), в пределах геоботанических районов. Fig. 11. Integral assessment of the number and occurrence of vascular plant species included in the Red Data Book of the Nenetsky Autonomous Okrug (2006) and in the Red Data Book of the Russian Federation (2008), within geobotanical districts.

Мозаика показателей ценности на территории округа индивидуальна для каждой модельной группы. Карта-схема интегральной оценки биологической ценности геоботанических районов построена на основе экспертных оценок. Приоритет при ее формировании отдан наиболее изученным группам - сосудистым растениям, птицам и млекопитающим с учетом данных по шмелям, дневным бабочкам и лишайникам. В тех случаях, когда данные по району отсутствовали, использовали сведения о ландшафтном разнообразии и почвенно-растительные характеристики, полученные при работе с картографическими материалами и многозональными спутниковыми снимками. Высокий уровень биологической ценности присущ островным, приморским и низкогорным районам НАО (рис. 12). Это согласуется с подготовленной с учетом результатов ГЭП-анализа схемой размещения ООПТ, служащих основой экологического каркаса НАО (Лавриненко, Лавриненко, 2011). В районах, обладающих высоким уровнем биологической ценности и пока не взятых под государственную охрану, в ближайшей перспективе будут созданы заказник «Колгуевский» и природный парк «Югорский», в дальнейшем планируется организовать заказники «Канин камень», «Яжмо-Несский» и «Святой Нос» (Лавриненко, Лавриненко, 2017).
Базы данных и геоинформачионная система по биологическому разнообразию Ненеикого автономного округа

ГИС по биоразнообразию НАО сформирована в среде ArcGis и состоит из топографических и тематических слоев: геоботаническое районирование; ключевые орнитологические территории; водно-болотные угодья; марши; территории, имеющие ключевое значение для сохранения редких и нуждающихся в особом внимании к их состоянию в природной среде объектов животного и растительного мира; береговые лежбища моржа; места концентрации выводковых нор песца; распространение и места гнездования промысловых птиц; существующие и планируемые ООПТ; техногенная нарушенность. Сформирована база архивных и актуальных многозональных спутниковых снимков (данных дистанционного зондирования - ДД3), а также архива метаданных ДДЗ на территорию НАО для мониторинга техногенных изменений природных комплексов.

Разработанный комплекс из объектноориентированной реляционной БД по разнообразию основных групп животных и растений и связанной с ней базы геоданных в среде ArcGis, служит для наглядного карто- 
графического отражения комплекса параметров биоразнообразия животных и растений в НАО. Сейчас БД включает сведения о 2035 видах животных (10 266 записей в исходной таблице данных о распространении птиц и 7993 записи в сводной таблице исходных данных по остальным группам) и 1640 видах растений (135045 записей). База данных масштабируема. То есть позволяет пополнять систему новыми данными как по уже включенным в систему таксонам животных и растений, так и новыми группами животных и растений в случае возникновения такой необходимости.

По каждой модельной группе организмов эксперты наполняли исходной информацией три блока (таблицы) БД. Среди них: 1) таксономический, характеризующий систематическое положение каждого вида и подвида и его широтное и долготное распространение (таблица ТАХА); 2) эколого-биологический, с указанием особенностей биологии и экологии вида (таблица BIODATA); 3) блок исходной информации - таблицы с характеристикой каждого коллекционного образца (таблица LOCALITIES). На завершающем этапе в среде MS Access сформирована единая объектно-ориентированная БД. Она имеет общую для всех групп таблицу местонахождений (рис. 13) за исключением базы по птицам, где зачастую документиру- ются визуальные наблюдения на маршрутах. Возможность организации связи ГИС и БД в среде MS Access позволяет формировать запросы как в среде ArcGis, так и непосредственно в БД, и отражать в ГИС результаты выполненного в БД запроса. Все атрибуты таблиц БД доступны при установлении отношений «один-к-одному» или «один-комногим» между таблицами атрибутивных данных ГИС и таблицами БД (рис. 14). Это позволяет использовать все поля БД в SQL SELECT-запросах из ГИС. Сохраняется и возможность пользоваться более удобными интерфейсными формами и сформированными и сохраненными в БД SQL SELECTзапросами для формирования динамичных слоев ГИС.

Все объектно-ориентированные блоки БД имеют универсальную структуру таблиц и отношений (связей). А доступ ко всей информации непосредственно из ArcGis позволяет выстроить комплекс стандартных запросов для каждой группы животных и растений для картографического отражения их разнообразия. Результатом выполнения базового запроса является построение карты точечного распространения таксона и далее - количественные и качественные оценки таксона в каждом местонахождении (численность, ландшафтная активность, параметры биологии, репродуктивные показатели и т.д.).

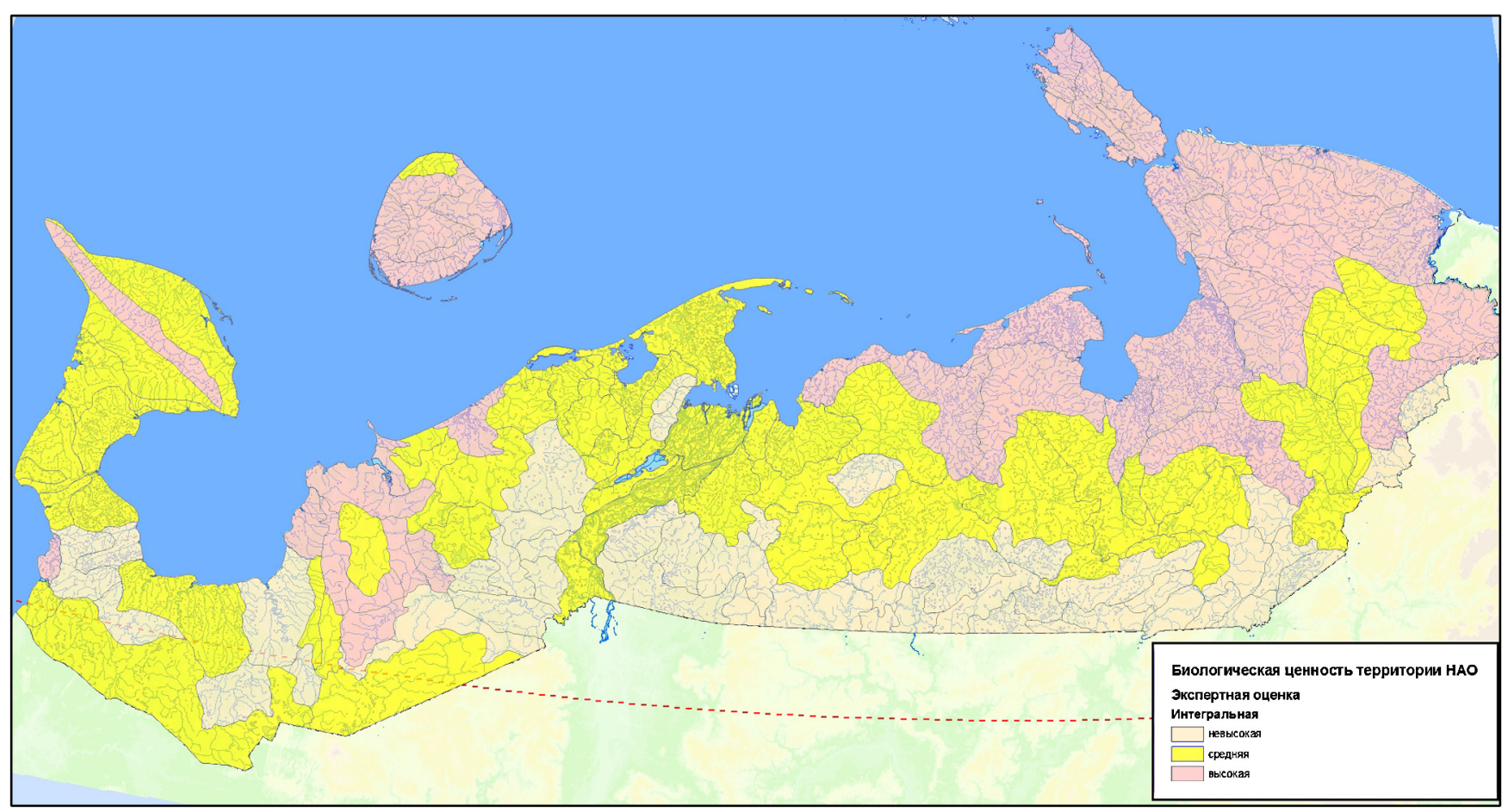

Рис. 12. Карта-схема интегральной экспертной оценки уровня биологической ценности геоботанических районов.

Fig. 12. The map of the integrated expert assessment of the biological value of geobotanical districts. 


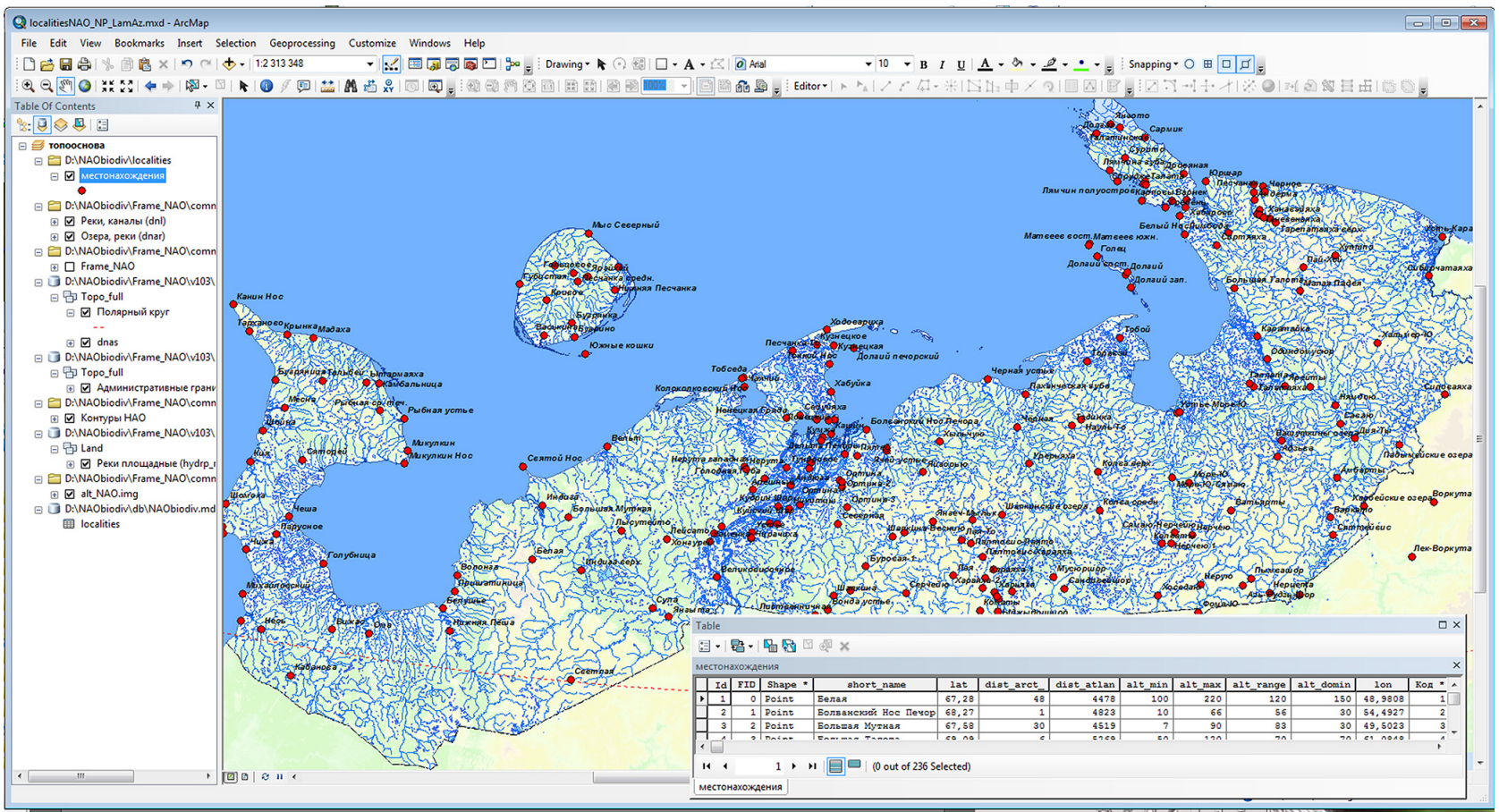

Рис. 13. Карта пунктов полевых исследований биоты, построенная на основе Базы данных местонахождений (фрагмент на врезке).

Fig. 13. The map of the study sites for biota field investigations, created on the basis of the database of locations (fragment on the map insertion).

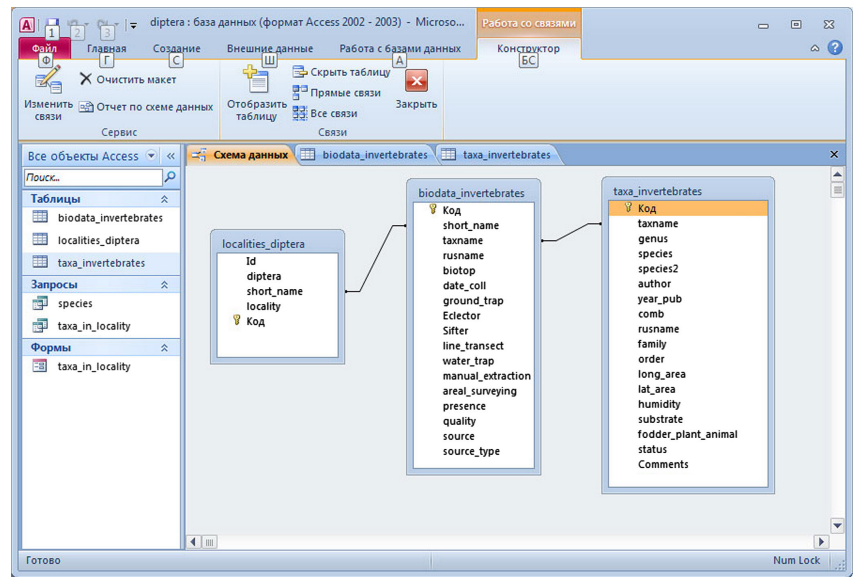

Рис. 14. Структура объектно-ориентированной базы данных, состоящей из трех таблиц. Показаны отношения «один-ко-многим» таблиц «localities - biodata» и «taxa biodata» для формирования набора стандартных запросов. Fig. 14. The structure of the Object-oriented database consisting of three tables. It indicates the connections «one-to-many» for tables «localities - biodata» and «taxa - biodata» to form a set of standard queries.

Разработанная структура БД позволяет отразить не только точечный ареал таксона, но и количественные характеристики популяций в каждом пункте. Средствами БД можно оценивать степень изученности основных групп животных и растений, выявлять территориальные пробелы в исследовании биоразнообразия и анализировать закономерности и основные тренды распределения биоты по территории НАО в зависимости от подзонального положения, ландшафтных условий и степени антропогенной нагрузки.

ГИС включает слои карты техногенной нарушенности растительного покрова НАО. Карта отражает наиболее масштабные и существенные нарушения, которые возможно показать в масштабе 1:200 000 и меньше (рис. 15). Проведены расчеты нарушенных площадей для каждого геоботанического района. Наиболее масштабные и существенные изменения растительности отмечены, прежде всего, вблизи населенных пунктов и в районах добычи полезных ископаемых. Они обусловлены воздействием объектов инфраструктуры на растительный покров. И если в целом для территории НАО доля площадных нарушений $0.2 \%$, то для отдельных районов она достигает 2\% (Харьягинский) и даже $8 \%$ (Припечорский). В последнем случае это обусловлено наличием обширных буферных зон в окрестностях г. Нарьян-Мар и малых населенных пунктов, многочисленных грунтовых дорог, соединяющих поселения, зон рекреации и т.п.

Подготовленная карта может быть основой для организации дистанционного мониторинга состояния природных комплексов НАО. Расчеты позволяют с уверенностью говорить о том, что на сегодняшний день техногенные нарушения растительного покрова на территории НАО локальны и в бо́льшей степени затрагивают Большеземельскую, Малоземельскую тундры и о-в Колгуев. 


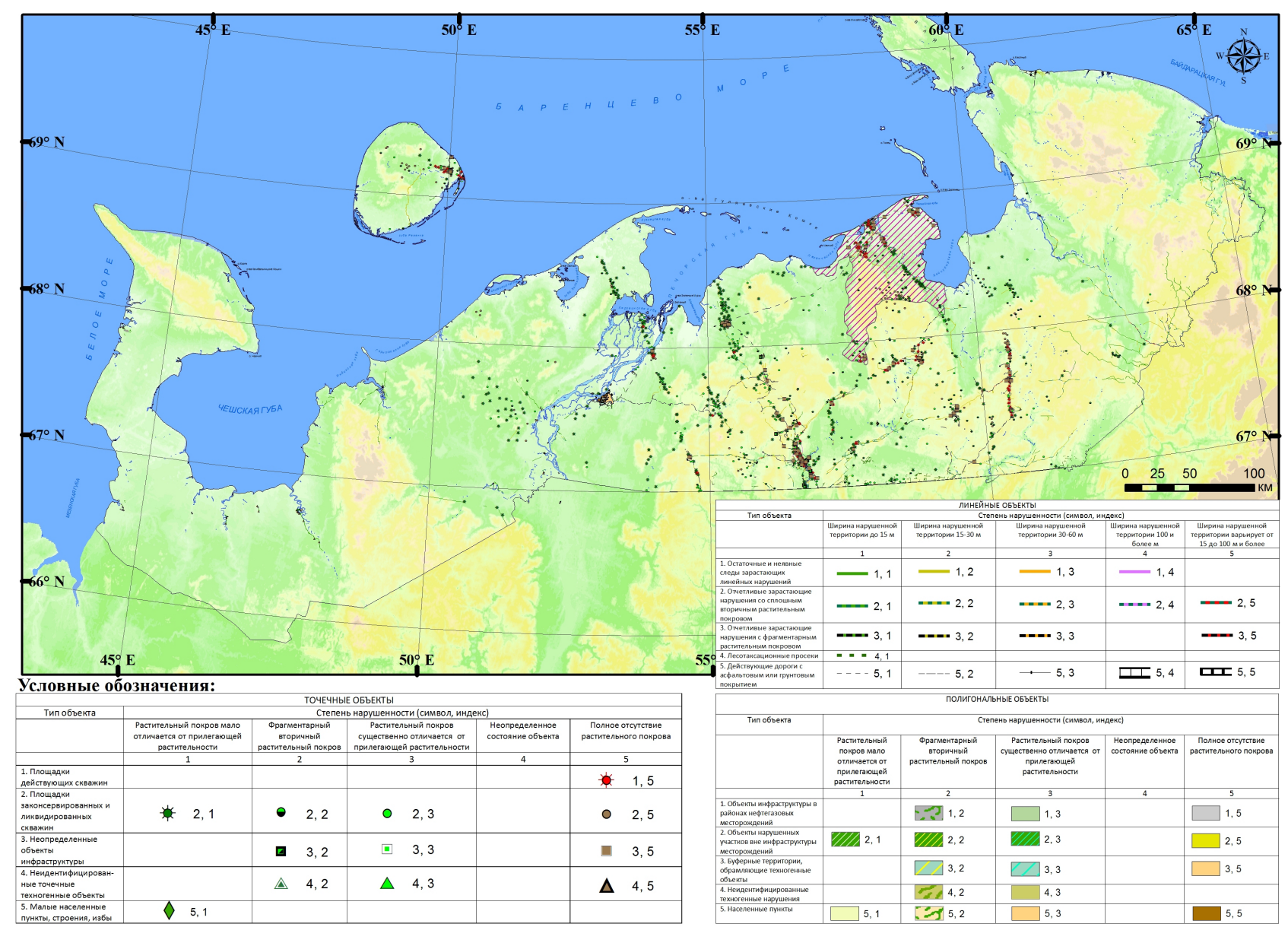

Рис. 15. Карта техногенной нарушенности растительного покрова Ненецкого автономного округа (исходный масштаб 1:200 000). Разными символами обозначены площадные и линейные нарушения: объекты инфраструктуры на территориях нефтегазовых месторождений, населенные пункты и зоны рекреации вокруг них, дороги, вторичная растительность на нарушенных землях. Штриховкой выделены районы, подверженные сильной техногенной нагрузке и, по результатам проекта, имеющие высокую биологическую ценность.

Fig. 15. The map of technogenic disturbance of vegetation cover in the Nenetsky Autonomous Okrug (original scale is 1:200 000). Various symbols indicate area disturbances and linear violations: infrastructure facilities in oil and gas fields, settlements and recreation zones around them, roads, secondary vegetation on disturbed lands. The stippled area indicates the areas subjected to intense technogenic pressure being of high biological value according to the results of the current project.

Был проведен совместный анализ слоев ГИС путем интегральной экспертной оценки уровня биологической ценности геоботанических районов, техногенной нарушенности растительного покрова и существующих ООПТ. Он позволил определить районы, которые при высокой биологической ценности подвержены сильной техногенной нагрузке, и не были включены в перспективный перечень создания ООПТ в НАО. Примером могут служить геоботанические районы между Паханческой и Хайпудырской губами в приморской части Большеземельской тундры (рис. 15; выделено штриховкой). Именно с учетом результатов проекта в 2017 г. здесь были созданы заказники «Паханческий» и «Хайпудырский» (рис. 1). Это позволило частично взять под охрану тер- ритории, свободные от лицензионных участков недропользователей.

\section{Заключение}

Результаты инвентаризации флоры и фауны НАО подтвердили, что особенно интенсивно в округе должны быть продолжены исследования таких плохо изученных в биоценотическом отношении групп животных, как двукрылые насекомые и микроартроподы, а среди растений - печеночники. Относительно слабая изученность ландшафтного и биологического разнообразия ряда районов (Югорский полуостров, Северный Тиман, п-ов Канин) свидетельствует о необходимости дальнейшего изучения биоты и природных комплексов этих территорий. 
Исполнители проекта были организаторами и авторами при подготовке 2-го издания (планируется к печати в 2019 г.) Красной книги Ненецкого автономного округа (первое издание в 2006 г.). По результатам оценки современной обеспеченности охраной видов животных и растений, включенных в Красные книги Ненецкого автономного округа (2006) и Российской Федерации (2001, 2008), подтверждена необходимость создания новых ООПТ на п-ове Канин, морском побережье Малоземельской и Большеземельской тундры, Северном Тимане и Югорском полуострове, а также в лесотундре на границе НАО и Республики Коми. С привлечением материалов, полученных в ходе выполнения проекта, подготовлены обоснования для создания заказников «Паханческий» и «Хайпудырский», утвержденных Постановлениями Администрации НАО №№ 277-п и 278-п от 30 августа 2017 г.

Созданная ГИС в настоящее время успешно встраивается в общую ГИС по НАО (КУ НАО Ненецкий информационно-аналитический центр, г. Нарьян-Мар; сайт http://gisnao. $\mathrm{ru} /$ ). Подготовленные слои, их комбинации, и генерализованные карты, отражающие ценность и нарушенность природных экосистем, являются надежным инструментом организации хозяйственной деятельности в условиях усиливающейся антропогенной нагрузки. Возможности пространственного анализа, заложенные в ГИС, позволяют выполнить расчеты по оценке биологической ценности, а также степени и интенсивности нарушений для любого территориального выдела (геоботанические районы, лицензионные участки, территории муниципальных районов, особо охраняемые природные территории и т. п.) и корректировать данные в динамике. Грамотное применение разработанной ГИС поможет сохранить наиболее уязвимые природные экосистемы и ландшафты округа, популяции многих редких и исчезающих видов растений и животных, а также другие ценные природные объекты, нуждающиеся в первоочередной охране.

\section{Благодарности}

Работы проведены при всемерной поддержке проекта ПРООН/ГЭФ и Минприроды России «Задачи сохранения биоразнообразия в политике и программах развития энергетического сектора России» (руководители проекта С.А. Шейнфельд, И.О. Костин). Обработка материалов экспедиции продолжается в настоящее время в рамках грантов РФФИ (№ 17-04-01603 «Членистоногие арктических мар- шей: особенности населения и региональная специфика» и № 18-05-60057 “"Позеленение” тундры как драйвер современной динамики арктической биоты»), темы госзадания № 0148-2019-0010 и Программы «Биоразнообразие и природные ресурсы России», картографические работы - гранта РФФИ (№ 16-08-00510 «Разработка и исследование методологии построения и создание прототипа информационной автоматизированной системы прогнозирования состояния растительного покрова Крайнего Севера на основе интегрированной обработки мульти- и гиперспектральных наземно-аэрокосмических данных, а также климатической информации»). Большую помощь в организации экспедиции оказали сотрудники государственного заповедника «Ненецкий» (в первую очередь, его директор - С.А. Золотой), региональный координатор проекта С.А. Уваров, работники Нарьян-Марской сельскохозяйственной опытной станции (директор - Т.М. Романенко), в ее проведении - Г.А. Тюсов (БИН РАН). Успех работ экспедиции 2015 г. был во многом определен безукоризненной работой Нарьян-Марского авиаотряда (генеральный директор - В.Е. Остапчук).

\section{Литература}

Алейников А.А., Алейникова А.М., Бочарников М.В., Глазов П.М., Головлев П.П., Головлева В.О., Груза Г.В., Добролюбова К.О., Евина А.И., Жбанова П.И., Замолодчиков Д.Г., Зенин Е.А., Калашникова Ю.А., Кожин М.Н., Кокорин А.О., Крыленко И.В., Крыленко И.Н., Кущева Ю.В., Липка О.Н., Микляев И.А., Микляева И.М., Никифоров В.В., Павлова А.Д., Постнова А.И., Пухова М.А., Ранькова Э.Я., Стишов М.С., Суткайтис О.К., Уваров С.А., Фомин С.Ю. 2014. Остров Вайгач: природа, климат и человек. М.: WWF. 542 с.

Анненкова А. 2010. Труднодоступный, но богатый // Нефть России (информационно-аналитический портал). №12. Точка доступа: http://www.oilru. com/nr/212/5188/

Ануфриев В.В. 2000. НЕ-003 Хайпудырская губа, о-ва Большой Зеленец, Долгий, Матвеев // Ключевые орнитологические территории международного значения в Европейской России. Ключевые орнитологические территории России. Т. 1 / Т.В. Свиридова, В.А. Зубакин (ред.). М.: Союз охраны птиц России. С. 78.

Ануфриев В.В. 2004. Наземные млекопитающие // Живая природа Ненецкого автономного округа / И.А. Лавриненко, О.В. Лавриненко (ред.). Нарьян-Мар. C. 59-68.

Ануфриев В.В. 2006. Орнитофауна островов Печорского моря // Вестник Поморского университета. Cер. естественные и точные науки. №1(9). С. 70-79.

Ануфриев В.В. 2010. Влияние изменений климата и погодных условий на пространственно-экологическую структуру популяции песца восточно-европейских тундр // Экология арктических и приарктических территорий. Материалы международного симпозиума. Архангельск. С. 299-302. 
Ануфриев В.М., Бобрецов А.В., Войлочников А.А., Нейфельд Н.Д., Кудрявцева Э.Н., Куприянова И.Ф., Петров А.Н., Полежаев Н.М., Пыстин А.Н. Сокольский С.М., Соловьев В.А., Турьева В.В., Юшков В.Ф. 1994. Фауна европейского Северо-Востока России. Млекопитающие. Т. 2, ч. 1. СПб.: Наука. 280 с.

Беспалая Ю.В., Аксенова О.В., Болотов И.Н., Кондаков А.В., Когут Я.Е. 2017. Фауна пресноводных моллюсков прибрежных низменностей Печорского моря (Большеземельская тундра, Ненецкий автономный округ) // Фауна Урала и Сибири. №1. С. 25-32.

Бизин М.С. 2016. Гамазовые клещи (Acari: Mesostigmata) маршей Печорского моря. Дипломная работа бакалавра. М.: МГУ. 54 с.

Всеволодова-Перель Т.С. 1988. Распространение дождевых червей на севере Палеарктики (в пределах СССР) // Биология почв Северной Европы / Д.А. Криволуцкий (ред.). М.: Наука. С. 84-99.

Гаврило М.В., Мартынова Д.М. 2017. Сохранение редких видов морской фауны и флоры, занесенных в Красную книгу Российской Федерации и красный список МСОП, в национальном парке «Русская Арктика» // Nature Conservation Research. Заповедная наука. Т. 2 (Suppl. 1). C. 10-42. DOI: 10241.89/ncr.2017.017

Железнова Г.В., Шубина Т.П. 2015. Мхи бассейна реки Белой (Северный Тиман, Ненецкий автономный округ) // Arctoa. T. 24. C. 204-209. DOI: 10.15298/arctoa.24.20

Железнова Г.В., Шубина Т.П., Дулин М.В., Бакалин В.А. 2007. Бриофиты юго-западной части острова Вайгач // Биоразнообразие растительного покрова Крайнего Севера: инвентаризация, мониторинг, охрана. Материалы всероссийской конференции (Сыктывкар, 22-26 мая 2006 г.). Сыктывкар. С. 30-39.

Зиновьева А.Н. 2013. Фауна полужесткокрылых (Heteroptera) окрестностей озер Харбейской системы (Большеземельская тундра) // Известия Коми научного центра УрО РАН. №1(13). С. 43-49.

Кищинский А.А. 1988. Орнитофауна северо-востока Азии: история и современное состояние. М.: Наука. 288 с.

Колесникова А.А., Долгин М.М., Конакова Т.Н. 2017. Жужелицы (Coleoptera, Carabidae). Сыктывкар: ИБ Коми НЦ УрО РАН. 340 с. (Фауна европейского северо-востока России. Жужелицы. Т. 8, ч. 4).

Константинова Н.А., Лавриненко О.В. 2002. К флоре Нераticae Ненецкого автономного округа (СевероВосток Европейской части России) // Ботанический журнал. Т. 87(9). С. 43-49.

Красная книга Ненецкого автономного округа / Матвеева Н.В., Лавриненко О.В., Лавриненко И.А. (ред.). Нарьян-Мар, 2006. 450 с.

Красная книга Российской Федерации (животные). М.: Астрель, 2001. 862 с.

Красная книга Российской Федерации (Растения и грибы). М.: Товарищество научных изданий КМК, 2008. 855 c.

Кривенко В.Г. (ред.). 2000. Водно-болотные угодья, внесенные в Перспективный список Рамсарской конвенции. №3. M.: Wetlands International Global Series. 490 c.
Кузьмин С.Л. 1999. Земноводные бывшего СССР. М.: Товарищество научных изданий КМК. 298 с.

Лавриненко И.А. 2012а. Дистанционный мониторинг растительности маршей побережья Баренцева моря // Современные проблемы дистанционного зондирования Земли из космоса. Т. 9(2). С. 67-72.

Лавриненко И.А. 2012б. Использование дистанционных методов при геоботаническом районировании восточно-европейских тундр // Современные проблемы дистанционного зондирования Земли из космоса. Т. 9(3). С. 269-276.

Лавриненко И.А., Лавриненко О.В. 2011. Создание экологической сети Ненецкого автономного округа, обеспечивающей репрезентативную представленность и сохранение полного спектра видового и ландшафтного разнообразия Российской Арктики. Отчет по Гранту WWF № WWF6/9Z1428/GLM. M.: WWF. 286 c.

Лавриненко О.В., Лавриненко И.А. 2014. Растительный покров оленьих пастбищ острова Колгуев: преемственность исследований и современные подходы // Ботаника: история, теория, практика (к 300-летию Ботанического института им. В.Л. Комарова Российской академии наук). СПб: Изд-во СПбГЭТУ «ЛЭТИ». С. 124-130.

Лавриненко О.В., Лавриненко И.А. 2017. Реализация схемы размещения ООПТ в Ненецком автономном округе и степень изученности биоразнообразия на их территориях // Материалы докладов межрегиональной конференции «Вклад особо охраняемых природных территорий Архангельской области в сохранение природного и культурного наследия» (21-23 ноября 2017 г.). Архангельск. С. 21-23.

Лавриненко О.В., Лавриненко И.А. 2018. Классификация растительности соленых и солоноватых маршей Большеземельской тундры (побережье Баренцева моря) // Фиторазнообразие Восточной Европы. Т. 12(3). C. 82-143. DOI: 10.24411/20728816-2018-10028

Лавриненко И.А., Лавриненко О.В., Николаева Н.М., Уваров С.А. 2015. Особо охраняемые природные территории Ненецкого автономного округа. Архангельск: Лоция. 80 с.

Лавриненко О.В., Петровский В.В., Лавриненко И.А. 2016. Локальные флоры островов и юго-восточного побережья Баренцева моря // Ботанический журнал. Т. 101(10). С. 1144-1190. DOI: 10.1134/ S0006813616100033

Макарова О.Л. 2012. Гамазовые клещи (Parasitiformes, Mesostigmata) европейской Арктики и их ареалы // Зоологический журнал. Т. 91(8). С. 907-927.

Макарова О.Л., Макаров К.В. 2006. Полужесткокрылые насекомые (Heteroptera) арктического острова Долгий (Баренцево море) // Зоологический журнал. Т. 85(6). С. 702-711.

Матвеева Н.В., Лавриненко О.В. 2011. Растительность маршей северо-востока Малоземельской тундры // Растительность России. №17-18. С. 45-69.

Мещерякова Е.Н., Берман Д.И. 2014. Устойчивость к отрицательным температурам и географическое рас- 
пространение дождевых червей (Oligochaeta, Lumbricidae, Moniligastridae) // Зоологический журнал. T. 93(1). C. 53-64. DOI: 10.7868/S0044513414010127

Минеев Ю.Н., Минеев О.Ю. 2009. Птицы Малоземельской тундры и дельты Печоры. СПб.: Наука. 263 с.

Минеев Ю.Н., Минеев О.Ю. 2012. Птицы Большеземельской тундры и Югорского полуострова. СПб.: Наука. 383 с.

Морозов В.В., Сыроечковский Е.Е. 2004. Материалы к познанию орнитофауны острова Колгуева // Орнитология. №31. С. 9-50.

Перель Т.С. 1979. Распространение и закономерности распределения дождевых червей фауны СССР. М.: Наука. 271 с.

Полежаев Н.М., Потелов В.А., Петров А.Н., Пыстин А.Н., Нейфельд Н.Д., Сокольский С.М., Тюрнин Б.Н. 1998. Фауна европейского Северо-Востока России. Млекопитающие. Т. 2, ч. 2. СПб.: Наука. 285 с.

Программный проект «Экология и охрана восточноевропейских тундр». Сыктывкар, 1992. 30 с.

Ребристая О.В. 1977. Флора востока Большеземельской тундры. Ленинград: Наука. 334 с.

Ручин А.Б., Егоров Л.В. 2017. Обзор видов насекомых Мордовского заповедника, включаемых в Красную Книгу Российской Федерации // Nature Conservation Research. Заповедная наука. T. 2(Suppl. 1). C. 2-9. DOI: $10.24189 /$ ncr.2017.016

Сергиенко В.Г. 2013. Конкретные флоры Канино-Мезенского региона. СПб., М.: Товарищество научных изданий КМК. 180 c.

Сорокина В.С. 2017. Мускоидные мухи (Diptera, Muscoidea) северных территорий России // Евразиатский энтомологический журнал. Т. 16(1). С. 44-56.

Стратегия социально-экономического развития Ненецкого автономного округа на перспективу до 2030 года. Часть 1: Социально-экономическое положение НАО. Администрация Ненецкого автономного округа. Нарьян-Мар, СПб: Фонд «Центр стратегических разработок “Северо-Запад”», 2008-2009. 68 с.

Татаринов А.Г. 2016. География дневных чешуекрылых европейского Северо-Востока России. М: Товарищество научных изданий КМК. 255 с.

Урбанавичюс Г.П., Лавриненко О.В., Урбанавичене И.Н. 2009. Лишайники острова Долгий и близлежащих островов Баренцева моря // Ботанический журнал. T. 94(5). С. 656-675.

Хапугин А.А., Силаева Т.Б., Варгот Е.В., Чугунов Г.Г., Гришуткина Г.А., Гришуткин О.Г., Письмаркина Е.В., Орлова Ю.С. 2017. Оценка таксонов первого тома Красной Книги Республики Мордовия (Россия), согласно категориям и критериям Красного списка МСОП // Nature Conservation Research. Заповедная наука. Т. 2(Suppl. 1). C. 164-189. DOI: 1024189/ncr.2017.004

Цвелев Н.Н. 1983. Plantaginaceae Juss. // Арктическая флора СССР. Т. 8. Ч. 2. Ленинград: Наука. С. 16-25.

Чернов Ю.И. 1984. Биологические предпосылки освоения арктической среды организмами различных таксонов // Фауногенез и филоценогенез / Ю.И. Чернов (ред.). М.: Наука. С. 154-174.
Чернов Ю.И., Макарова О.Л., Пенев Л.Д., Хрулева О.А. 2014. Отряд жесткокрылых (Insecta, Coleoptera) в фауне Арктики. Сообщение 1. Состав фауны // Зоологический журнал. Т. 93(1). С. 7-44. DOI: 10.7868/ S004451341401005X

Штегман Б.К. 1938. Основы орнитогеографического деления Палеарктики // Фауна СССР. Птицы. Т. 1. М., Ленинград: Издательство АН СССР. 157 с.

Юрцев Б.А., Толмачев А.И., Ребристая О.В. 1978. Флористическое ограничение и разделение Арктики // Арктическая флористическая область / Б.А. Юрцев (ред.). Ленинград: Наука. С. 9-104.

Babenko A., Potapov M., Taskaeva A. 2017. The Collembolan fauna of the East European tundra // Russian Entomological Journal. Vol. 26(1). P. 1-30.

Bellard C., Bertelsmeier C., Leadley P., Thuiller W., Courchamp, F. 2012. Impacts of climate change on the future of biodiversity // Ecology Letters. Vol. 15(4). P. 365-377. DOI: 10.1111/j.1461-0248.2011.01736.x

Callaghan T., Björn L., Chernov Y., Chapin T., Christensen T., Huntley B., Ims R., Johansson M., Jolly D., Jonasson S., Matveyeva N., Panikov N., Oechel W., Shaver G., Elster J., Henttonen H., Laine K., Taulavuori E., Zöckler C. 2004. Biodiversity, Distributions and Adaptations of Arctic Species in the Context of Environmental Change // AMBIO: A Journal of the Human Environment. Vol. 33(7). P. 404-417. DOI: 10.1579/0044-7447-33.7.474

Coulson S.J., Convey P., Aakra K., Aarvik L., Avila-Jimenez M.L., Babenko A., Biersma E., Bostrom S., Brittain J.E., Carlsson A., Christoffersen K.S., De Smet W.H., Ekrem T., Fjellberg A., Fureder L., Gustafsson D., Gwiazdowicz D.J., Hansen L.O., Holmstrup M., Hulle M., Kaczmarek L., Kolicka M., Kuklin V., Lakka H.-K., Lebedeva N., Makarova O., Maraldo K., Melekhina E., Odegaard F., Pilskog H.E., Simon J.C., Sohlenius B., Solhoy T., Soli G., Stur E., Tanasevitch A., Taskaeva A., Velle G., Zawierucha K., Zmudczynska-Skarbek K. 2014. The terrestrial and freshwater invertebrate biodiversity of the archipelagoes of the Barents Sea; Svalbard, Franz Josef Land and Novaya Zemlya // Soil Biology and Biochemistry. Vol. 68. P. 440-470. DOI: 10.1016/j.soilbio.2013.10.006

van der Graaf A.J., Lavrinenko O.V., Elsakov V., van Eerden M.R., Stahl J. 2004. Habitat use of barnacle geese at a subarctic salt marsh in the Kolokolkova Bay, Russia // Polar Biology. Vol. 27(11). P. 651-660. DOI: 10.1007/ s00300-004-0623-3

Hofgaard A., Harper K.A., Golubeva E. 2012. The role of the circumarctic forest-tundra ecotone for Arctic biodiversity // Biodiversity. Vol. 13(3-4). P. 174-181. DOI: $10.1080 / 14888386.2012 .700560$

Khaustov A.A., Makarova O.L. 2016. First record of the mite genus Rackia (Acari: Heterostigmatina: Neopygmephoridae) from arctic Russia with the description of a new species // Acarina. Vol. 24(1). P. 55-60. DOI: 10.21684/0132-8077.2016.24.1.55.60

Koch L. 1879. Arachniden aus Sibirien und Novaja Semlja eingesammelt von der schwedischen Expedition im Jahre 1875 // Kongliga svenska Vetenskaps-Akademiens Handlingar. Vol. 16(5). P. 1-136. 
Kruckenberg H., Kondratyev A., Zöckler C., Zaynagutdinova E., Mooij J.H. 2012. Breeding waders on Kolguev Island, Barents Sea, Northern Russia, 2006-2008 // Wader Study Group Bulletin. Vol. 119(2). P. 102-113.

Makarova O.L. 2015. The fauna of free-living mites (Acari) of Greenland // Entomological Review. Vol. 95(1). P. 108-125. DOI: 10.1134/S0013873815010133

Makarova O.L., Böcher J. 2009. Diversity and geographical ranges of Greenland mites (Acari: Oribatida and Mesostigmata) // Species and Communities in Extreme Environments / S.I. Golovatch, O.L. Makarova, A.B. Babenko, L.D. Penev (Eds). Sofia - Moscow: Pensoft Publishers \& Moscow: KMK Scientific Press Ltd. P. 165-186.

Matveyeva N., Chernov Y. 2000. Biodiversity of terrestrial ecosystems // The Arctic. Environment, people, policy / M. Nuttall, T.V. Callaghan (Eds). Newark: Harwood Academic Publishers. P. 233-274.

Meltofte H. (Ed.). 2013. Arctic Biodiversity Assessment. Status and Trends in Arctic Biodiversity. Synthesis. Akureiry: Conservation of Arctic Flora and Fauna (CAFF), Arctic Council. 132 p.

Mizin I.A., Sipko T.P., Davydov A.V., Gruzdev A.R. 2018. The wild reindeer (Rangifer tarandus: Cervidae, Mammalia) on the Arctic islands of Russia: a review // Nature Conservation Research. Vol. 3(3). P. 1-14. DOI: 10.24189/ncr.2018.040

Prokin A.A., Makarova O.L., Petrov P.N. 2017. Water beetles (Coleoptera) of coastal areas of the Bolshezemelskaya Tundra, extreme northeastern Europe // Aquatic Insects. Vol. 38(4). P. 197-218. DOI: 10.1080/01650424.2017.1387270

Raynolds M.K., Walker D.A., Epstein H.E., Pinzon J.E., Tucker C.J. 2012. A new estimate of tundra-biome phytomass from trans-Arctic field data and AVHRR NDVI // Remote Sensing Letters. Vol. 3(5). P. 403-411. DOI: $10.1080 / 01431161.2011 .609188$

Seebohm H. 1880. Siberia in Europe: a Visit to the Valley of the Petchora, in North-East Russia with Description of the Natural History, Migration of Birds, etc. London: John Murray. 311 p.

Stekolshchikov A.V. 2017. Contribution to the aphid fauna (Hemiptera: Sternorrhyncha, Aphidomorpha) of the Nenets Autonomous Okrug // Entomologist's Monthly Magazine. Vol. 153. P. 131-155.

Tanasevitch A.V., Khruleva O.A. 2017. Spiders (Aranei) of the typical tundra subzone of the Yugorsky Peninsula, Russia // Arthropoda Selecta. Vol. 26(4). P. 341-368. DOI: 10.15298/arthsel.26.4.10

Vinarski M.V., Aksenova O.V., Bespalaya Y.V., Bolotov I.N., Schniebs K., Gofarov M.Yu., Kondakov A.V. 2016. Radix dolgini: The integrative taxonomic approach supports the species status of a Siberian endemic snail (Mollusca, Gastropoda, Lymnaeidae) // Comptes Rendus Biologies. Vol. 339(1). P. 24-36. DOI: 10.1016/j.crvi.2015.11.002

Weigmann G. 2008. Oribatid mite communities in Atlantic salt marshes: an ecological and biogeographical comparison between German and Portuguese sea shores // Integrative Acarology, Proceedings of the sixth Congress of the
European Association of Acarologists / M. Bertrand, S. Kreiter, K.D. McCoy, A. Migeon, M. Navajas, M.-S. Tixier, L. Vial (Eds.). Montpellier. P. 275-283.

\section{References}

Aleynikov A.A., Aleynikova A.M., Bocharnikov M.V., Glazov P.M., Golovlev P.P., Gruza G.V., Dobrolyubova K.O., Evina A.I., Zhbanova P.I., Zamolodchikov D.G., Zenin E.A., Kalashnikova Yu.A., Kozhin M.N., Kokorin A.O., Krylenko I.V., Krylenko I.N., Kushcheva Yu.V., Lipka O.N., Miklyaev I.A., Miklyaeva I.M., Nikiforov V.V., Pavlova A.D., Postnova A.I., Pukhova M.A., Rankova E.Ya., Stishov M.S., Sutkaytis O.K., Uvarov S.A., Fomin S.Yu. 2014. Vaigach Island: nature, climate and people. Moscow: WWF. 542 p. [In Russian]

Annenkova A. 2010. Hard to reach, but rich. In: Oil of Russia (information and analytical portal) 12. Available from: http://www.oilru.com/nr/212/5188/ [In Russian]

Anufriev V.M., Bobretsov A.B., Voilochnikov A.A., Neyfeld N.D., Kudryavtseva E.N., Kupriyanova I.F., Petrov A.N., Polezhaev N.M., Pystin A.N. Sokolskiy S.M., Solovyev V.A., Turyeva V.V., Yushkov V.F. 1994. Fauna of the European North-East of Russia. Mammals. Vol. 2, Part 1. St. Petersburg: Nauka. 280 p. [In Russian]

Anufriev V.V. 2000. NE-003 Khaipudyrskaya Bay, Islands Bolshoy Zelenets, Dolgiy, Matveyev. In: T.V. Sviridova, V.A. Zubakin (Eds.): Key Ornithological Areas of International Value in the European Russia. Key Ornithological Areas of Russia. Vol. 1. Moscow: Russian Bird Conservation Union. P. 78. [In Russian]

Anufriev V.V. 2004. Terrestrial mammals. In: I.A. Lavrinenko, O.V. Lavrinenko (Eds.): Live Nature of the Nenetsky Autonomous Okrug. Narjan-Mar. P. 59-68. [In Russian]

Anufriev V.V. 2006. Ornitofauna of the Pechora Sea islands. Vestnik of the Pomor University. Series Natural and Exact Sciences 1(9): 70-79. [In Russian]

Anufriev V.V. 2010. Influence of climate changes and weather conditions on spatial-ecological structure of Arctic fox population in East European tundra. In: Ecology of Arctic and Subarctic Areas. Proceedings of International Symposium. Arhangelsk. P. 299-302. [In Russian]

Babenko A., Potapov M., Taskaeva A. 2017. The Collembolan fauna of the East European tundra. Russian Entomological Journal 26(1): 1-30.

Bellard C., Bertelsmeier C., Leadley P., Thuiller W., Courchamp, F. 2012. Impacts of climate change on the future of biodiversity. Ecology Letters 15(4): 365-377. DOI:10.1111/j.1461-0248.2011.01736.x

Bespalaya Yu.V., Aksenova O.V., Bolotov I.N., Kondakov A.V., Kogut Ya.E. 2017. Fauna of freshwater mollusks of the Pechora Sea coastal lowlands (Bolshezemelskaya Tundra, Nenetsky Autonomous Okrug). In: Fauna of Ural and Siberia. Vol. 1. P. 25-32. [In Russian]

Bizin M.S. 2016. Gamasid mites (Acari: Mesostigmata) of the Pechora Sea marshes. BSc. Thesis. Moscow: Moscow State University. 54 p. [In Russian]

Callaghan T., Björn L., Chernov Y., Chapin T., Christensen T., Huntley B., Ims R., Johansson M., Jolly D., Jonasson 
S., Matveyeva N., Panikov N., Oechel W., Shaver G., Elster J., Henttonen H., Laine K., Taulavuori E., Zöckler C. 2004. Biodiversity, Distributions and Adaptations of Arctic Species in the Context of Environmental Change. AMBIO: A Journal of the Human Environment 33(7): 404-417. DOI: 10.1579/0044-7447-33.7.474

Chernov Yu.I. 1984. Biological background of the Arctic environment expansion by the organisms of various taxa. In: Yu.I. Chernov (Ed.). Faunogenesis and Phylocenogenesis. Moscow: Nauka. P. 154-174. [In Russian]

Chernov Yu.I., Makarova O.L., Penev L.D., Khruleva O.A. 2014. The beetles (Insecta, Coleoptera) in the Arctic Fauna. Communication 1. Faunal composition. Zoologicheskii Zhurnal 93(1): 7-44. DOI: 10.7868/ S004451341401005X

Coulson S.J., Convey P., Aakra K., Aarvik L., Avila-Jimenez M.L., Babenko A., Biersma E., Bostrom S., Brittain J.E., Carlsson A., Christoffersen K.S., De Smet W.H., Ekrem T., Fjellberg A., Fureder L., Gustafsson D., Gwiazdowicz D.J., Hansen L.O., Holmstrup M., Hulle M., Kaczmarek L., Kolicka M., Kuklin V., Lakka H.K., Lebedeva N., Makarova O., Maraldo K., Melekhina E., Odegaard F., Pilskog H.E., Simon J.C., Sohlenius B., Solhoy T., Soli G., Stur E., Tanasevitch A., Taskaeva A., Velle G., Zawierucha K., ZmudczynskaSkarbek K. 2014. The terrestrial and freshwater invertebrate biodiversity of the archipelagoes of the Barents Sea; Svalbard, Franz Josef Land and Novaya Zemlya. Soil Biology and Biochemistry 68: 440-470. DOI: $10.1016 /$ j.soilbio.2013.10.006

Gavrilo M.V., Martynova D.M. 2017. Conservation of rare species of marine flora and fauna of the Russian Arctic National Park, included in the Red Data Book of the Russian Federation and in the IUCN Red List. Nature Conservation Research 2(Suppl. 1): 10-42. DOI: 10241.89/ncr.2017.017 [In Russian]

van der GraafA.J., Lavrinenko O.V., Elsakov V., van Eerden M.R., Stahl J. 2004. Habitat use of barnacle geese at a subarctic salt marsh in the Kolokolkova Bay, Russia. Polar Biology 27(11): 651-660. DOI: 10.1007/s00300-004-0623-3

Hofgaard A., Harper K.A., Golubeva E. 2012. The role of the circumarctic forest-tundra ecotone for Arctic biodiversity. Biodiversity 13(3-4): 174-181. DOI: 10.1080/14888386.2012.700560

Khapugin A.A., Silaeva T.B., Vargot E.V., Chugunov G.G., Grishutkina G.A., Grishutkin O.G., Pismarkina E.V., Orlova Ju.S. 2017. Estimation of taxa included in the first volume of the Red Data Book of the Republic of Mordovia (Russia) using the IUCN Red List Categories and Criteria. Nature Conservation Research 2(Suppl. 1): 164-189. DOI: 1024189/ncr.2017.004 [In Russian]

Khaustov A.A., Makarova O.L. 2016. First record of the mite genus Rackia (Acari: Heterostigmatina: Neopygmephoridae) from arctic Russia with the description of a new species. Acarina 24(1): 55-60. DOI: 10.21684/0132-8077.2016.24.1.55.60

Kishchinskiy A.A. 1988. The Avifauna of the North-East of Asia: History and Current Status. Moscow: Nauka. 288 p. [In Russian]
Koch L. 1879. Arachniden aus Sibirien und Novaja Semlja eingesammelt von der schwedischen Expedition im Jahre 1875. Kongliga svenska Vetenskaps-Akademiens Handlingar 16(5): 1-136.

Kolesnikova A.A., Dolgin M.M., Konakova T.N. 2017. Ground Beetles (Coleoptera, Carabidae). Syktyvkar: Institute of Biology, Komi Scientific Centre of Uran Branch of RAS. 340 p. (Fauna of the European NorthEast of Russia. Vol. 8, Part 4.). [In Russian]

Konstantinova N.A., Lavrinenko O.V. 2002. To the Hepaticae flora of the Nenetsky Autonomous Okrug (North-East of the European part of Russia). Botanichesky Zhurnal 87(9): 43-49. [In Russian]

Krivenko V.G. (Ed.). 2000. Wetlands of Russia. Wetlands, Included in the Perspective List of the Ramsar Convention. №3. Moscow: Wetlands International Global Series. 490 p. [In Russian]

Kruckenberg H., Kondratyev A., Zöckler C., Zaynagutdinova E., Mooij J.H. 2012. Breeding waders on Kolguev Island, Barents Sea, Northern Russia, 2006-2008. Wader Study Group Bulletin 119(2): 102-113.

Kuzmin S.L. 1999. Amphibians of the Former USSR. Moscow: KMK Scientific Press Ltd. 298 p. [In Russian]

Lavrinenko I.A. 2012a. Using remote sensing for geobotanical subdivision of the East European tundra. Sovremennye Problemy Distantsionnogo Zondirovaniya Zemli iz Kosmosa 9(3): 269-276. [In Russian]

Lavrinenko I.A. 2012b. Remote monitoring of the Barents Sea coastal marshes vegetation. Sovremennye Problemy Distantsionnogo Zondirovaniya Zemli iz Kosmosa 9(2): 67-72. [In Russian]

LavrinenkoI.A.,Lavrinenko O.V.2011. Creating the Ecological Networks in the Nenetsky Autonomous District, Ensuring Representation and Protection of the Complete Range of Species and Landscape Diversity of the Russian Arctic. Report of Grant WWF № WWF6/9Z1428/GLM. Moscow: WWF. 286 p. [In Russian]

Lavrinenko O.V., Lavrinenko I.A. 2014. The plant cover of reindeer pastures on the Kolguev Island: succession of research and current approaches. In: Botany: History, Theory, Practice. Proceedings of International Scientific Conference. St. Petersburg: Izdatelstvo SPbGETU «LETI». P. 124-130. [In Russian]

Lavrinenko O.V., Lavrinenko I.A. 2017. Implementation of the scheme for the placement of protected areas in the Nenetsky Autonomous Okrug and the degree of biodiversity research in these territories. In: Proceedings of the Interregional Conference "The Contribution of Protected Areas in the Arkhangelsk Region to the Preservation of Natural and Cultural Heritage» (21-23 November, 2017). Arkhangelsk. P. 21-23. [In Russian]

Lavrinenko O.V., Lavrinenko I.A. 2018. Classification of salt and brackish marsh vegetation of the Bolschezemelskaya Tundra (Barents Sea coastal areas). Phytodiversity of Eastern Europe 12(3): 82-143. DOI: 10.24411/20728816-2018-10028 [In Russian]

Lavrinenko I.A., Lavrinenko O.V., Nikolaeva N.M., Uvarov S.A. 2015. Protected Areas of Nenetsky Autonomous Okrug. Arhangelsk: Lotsiya. 80 p. [In Russian] 
Lavrinenko O.V., Petrovskiy V.V., Lavrinenko I.A. 2016. Local floras of islands and the coast of the south-eastern part of Barents Sea. Botanichesky Zhurnal 101(10): 1144-1190. DOI: 10.1134/S0006813616100033 [In Russian]

Makarova O.L. 2012. Gamasid mites (Parasitiformes, Mesostigmata) of the European Arctic and their distribution patterns. Zoologicheskii Zhurnal 91(8): 907-927.

Makarova O.L. 2015. The fauna of free-living mites (Acari) of Greenland. Entomological Review 95(1): 108-125. DOI: $10.1134 / \mathrm{S} 0013873815010133$

Makarova O.L., Böcher J. 2009. Diversity and geographical ranges of Greenland mites (Acari: Oribatida and Mesostigmata). In: S.I. Golovatch, O.L. Makarova, A.B. Babenko, L.D. Penev (Eds): Species and Communities in Extreme Environments. Sofia Moscow: Pensoft Publishers \& Moscow: KMK Scientific Press Ltd. P. 165-186.

Makarova O.L., Makarov K.V. 2006. True bugs (Heteroptera) from Arctic Dolgii Island, the Barents Sea. Zoologicheskii Zhurnal 85(6): 423-432. DOI: 10.1134/ S0013873806040063

Matveyeva N., Chernov Y. 2000. Biodiversity of terrestrial ecosystems. In: M. Nuttall, T.V. Callaghan (eds): The Arctic. Environment, people, policy. Newark: Harwood Academic Publishers. P. 233-274.

Matveyeva N.V., Lavrinenko O.V. 2011. Marsh vegetation in the north-east of Malozemelskaya Tundra. Rastitelnost Rossii 17-18: 45-69. [In Russian]

Meltofte H. (Ed.). 2013. Arctic Biodiversity Assessment. Status and Trends in Arctic Biodiversity. Synthesis. Akureiry: Conservation of Arctic Flora and Fauna (CAFF), Arctic Council. 132 p.

Meshcheryakova E.N., Berman D.I. 2014. The cold-hardiness and geographic distribution of earthworms (Oligochaeta, Lumbricidae, Moniligastridae). Zoologicheskii Zhurnal 93(1): 53-64. DOI: 10.7868/S0044513414010127

Mineyev Yu.N., Mineyev O.Yu. 2009. Birds of the Malozemelskaya Tundra and Pechora Delta. St. Petersburg: Nauka. 263 p. [In Russian]

Mineyev Yu.N., Mineyev O.Yu. 2012. Birds of the Bolshezemelskaya Tundra and Yugorsky Peninsula. St. Petersburg: Nauka. 383 p. [In Russian]

Mizin I.A., Sipko T.P., Davydov A.V., Gruzdev A.R. 2018. The wild reindeer (Rangifer tarandus: Cervidae, Mammalia) on the arctic islands of Russia: a review. Nature Conservation Research 3(3): 1-14. DOI: 10.24189/ncr.2018.040

Morozov V.V., Syroechkovsky E.E. 2004. Data to the knowing the ornitofauna of the Kolguev Island. Ornitologia 31: 9-50. [In Russian]

Perel T.S. 1979. Spread and Distribution Patterns of Earthworms of the USSR Fauna. Moscow: Nauka. 271 p. [In Russian]

Polezhaev N.M., Potelov V.A., Petrov A.N., Pystin A.N., Neifeld N.D., Sokolskiy S.M., Tyurnin B.N. 1998. Fauna of the European North-East of Russia. Mammals. Vol. 2, Part 2. St. Petersburg: Nauka. 285 p. [In Russian]

Programm Project «Ecology and Protection of East European Tundras». Syktyvkar, 1992. 30 p. [In Russian]
Prokin A.A., Makarova O.L., Petrov P.N. 2017. Water beetles (Coleoptera) of coastal areas of the Bolshezemelskaya Tundra, extreme northeastern Europe. Aquatic Insects 38(4).P.197-218.DOI: 10.1080/01650424.2017.1387270

Raynolds M.K., Walker D.A., Epstein H.E., Pinzon J.E., Tucker C.J. 2012. A new estimate of tundra-biome phytomass from trans-Arctic field data and AVHRR NDVI. Remote Sensing Letters 3(5): 403-411. DOI: 10.1080/01431161.2011.609188

Red Data Book of the Nenetsky Autonomous Okrug. NaryanMar, 2006. 450 p. [In Russian]

Red Data Book of Russian Federation (Animals). Moscow: Astrel, 2001. 860 p. [In Russian]

Red Data Book of Russian Federation (plants and fungi). Moscow: KMK Scientific Press Ltd., 2008. 855 p. [In Russian]

Rebristaya O.V. 1977. Flora of the East of Bolshezemelskaya Tundra. Leningrad: Nauka. 334 p. [In Russian]

Ruchin A.B., Egorov L.V. 2017. Overview of insect species included in the Red Data Book of Russian Federation in the Mordovia State Nature Reserve. Nature Conservation Research 2 (Suppl. 1): 2-9. DOI: 10.24189/ncr.2017.016 [In Russian]

Seebohm H. 1880. Siberia in Europe: a Visit to the Valley of the Petchora, in North-East Russia with Description of the Natural History, Migration of Birds, etc. London: John Murray. 311 p.

Sergienko V.G. 2013. Local Floras of Kanin-Mezen Region. St. Petersburg; Moscow: KMK Scientific Press Ltd. 180 p. [In Russian]

Shtegman B.K. 1938. Basis of Ornithogeographical Division of the Palaearctic. Fauna of USSR. Aves. Vol. 1. Moscow; Leningrad: Publisher of AS USSR. 157 p. [In Russian]

Sorokina V.S. 2017. The Muscoidea Flies (Diptera) of the northern territories of Russia. Euroasian Entomological Journal 16(1): 44-56. [In Russian]

Stekolshchikov A.V. 2017. Contribution to the aphid fauna (Hemiptera: Sternorrhyncha, Aphidomorpha) of the Nenets Autonomous Okrug. Entomologist's Monthly Magazine 153: 131-155.

Strategy of socio-economic development of the Nenetsky Autonomous Okrug to the perspective up to 2030. Part 1: Socio-economic situation of the NAO. Naryan-Mar - St. Petersburg: Administration of the Nenetsky Autonomous Okrug. Foundation «Centre for Strategic Research "North-West" », 2008-2009. 68 p. [In Russian]

Tanasevitch A.V., Khruleva O.A. 2017. Spiders (Aranei) of the typical tundra subzone of the Yugorsky Peninsula, Russia. Arthropoda Selecta 26(4): 341-368. DOI: 10.15298/arthsel.26.4.10

Tatarinov A.G. 2016. Geography of Daytime Lepidoptera of the European North-East of Russia. Moscow: KMK Scientific Press Ltd. 255 p. [In Russian]

Tzvelev N.N. 1983. Plantaginaceae Juss. In: Arctic Flora of USSR. Vol. 8. Part 2. Leningrad: Nauka. P. 16-25. [In Russian]

Urbanavichus G.P., Lavrinenko O.V., Urbanavichene I.N. 2009. The lichens of Dolgii and adjacent islands of the Barents Sea. Botanichesky Zhurnal 94(5): 656-675. [In Russian] 
Vinarski M.V., Aksenova O.V., Bespalaya Y.V., Bolotov I.N., Schniebs K., Gofarov M.Yu., Kondakov A.V. 2016. Radix dolgini: The integrative taxonomic approach supports the species status of a Siberian endemic snail (Mollusca, Gastropoda, Lymnaeidae). Comptes Rendus Biologies 339(1): 24-36. DOI: 10.1016/j.crvi.2015.11.002

Vsevolodova-Perel T.S. 1988. Distribution of earthworms in the north of the Palaearctic (within the USSR). In: D.A. Krivolutskij (Ed.): Soil Biology of the Northern Europe. Moscow: Nauka. P. 84-99. [In Russian]

Weigmann G. 2008. Oribatid mite communities in Atlantic salt marshes: an ecological and biogeographical comparison between German and Portuguese sea shores. In: M. Bertrand, S. Kreiter, K.D. McCoy, A. Migeon, M. Navajas, M.-S. Tixier, L. Vial (Eds.): Integrative Acarology: Proceedings of the Sixth Congress of the European Association of Acarologists. Montpellier. P. 275-283.
Yurtsev B.A., Tolmachev A.I., Rebristaya O.V. 1978. Floristic limitation and division of the Arctic In: B.A. Yurtsev (Ed.): Arctic Floristic Region. Leningrad: Nauka. P. 9-104. [In Russian]

Zheleznova G.V., Shubina T.P. 2015. Mosses of the Belaya River basin (Northern Timan, Nenetsky Autonomous Okrug). Arctoa 24: 204-209. DOI: 10.15298/ arctoa.24.20 [In Russian]

Zheleznova G.V., Shubina T.P., Dulin M.V., Bakalin V.A. 2007. Bryophytes of the south-western part of the Vaigach Island. In: Biodiversity of Plant Cover of the North: Inventory, Monitoring, Conservation: Proceedings of All-Russian Conference (Syktyvkar, 22 26 May 2006). Syktyvkar. P. 30-39. [In Russian]

Zinovyeva A.N. 2013. The true bug fauna (Heteroptera) in neighbourhoods of Kharbey system lakes (Bolshezemelskaya Tundra). Proceedings of the Komi Science Centre of the Ural Division of RAS 1(13): 43-49. [In Russian]

\title{
BIODIVERSITY REVISION OF A LARGE ARCTIC REGION AS A BASIS FOR ITS MONITORING AND PROTECTION UNDER CONDITIONS OF ACTIVE ECONOMIC DEVELOPMENT (NENETSKY AUTONOMOUS OKRUG, RUSSIA)
}

\author{
Viatcheslav V. Rozhnov', Igor A. Lavrinenko², Vladimir Yu. Razzhivin², Olga L. Makarova1,*, \\ Olga V. Lavrinenko², Vladimir V. Anufriev ${ }^{3}$, Anatoly B. Babenko', Mikhail S. Bizin ${ }^{1}$, \\ Petr M. Glazov ${ }^{4}$, Sergey V. Goryachkin ${ }^{4}$, Alla A. Kolesnikova ${ }^{5}$, \\ Nadezhda V. Matveyeva ${ }^{2}$, Sergey V. Pestov ${ }^{5}$, Vladislav V. Petrovskii ${ }^{2}$, \\ Olga B. Pokrovskaya ${ }^{1}$, Andrei V. Tanasevich ${ }^{1}$, Andrei G. Tatarinov ${ }^{5}$
}

\author{
${ }^{1}$ Severtsov Institute of Ecology and Evoluton of RAS, Russia \\ *e-mail:olmakarova@mail.ru \\ ${ }^{2}$ Komarov Botanical Institute of RAS, Russia \\ ${ }^{3}$ Laverov Federal Centre for Integrated Arctic Research of RAS, Russia \\ ${ }^{4}$ Institute of Geography of RAS, Russia \\ ${ }^{5}$ Institute of Biology, Komi Science Centre, Ural Branch of RAS, Russia
}

In the scope of implementing a UNDP / GEF / Ministry of Nature project, a database and a GIS to consider the biodiversity of the Nenetsky Autonomous Okrug were developed. They include information on 2035 animal and 1640 plant species, belonging to 15 model groups. Data were obtained using publications and unpublished sources, the results of studying collections / herbaria of four institutes of the Russian Academy of Sciences, and data of fieldwork (2015) conducted in three coastal areas of Bolshezemelskaya Tundra. The taxonomic richness of the Nenetsky Autonomous Okrug biota is not lower (even higher in some animal groups) than in other large Arctic regions (e.g. Taymyr and Greenland). Some new vegetation syntaxa have been described. And some phytogeographic boundaries have been established. Several animal taxa have been described for the first time for science. Some of species were neither previously recorded in the Nenetsky Autonomous Okrug nor formerly known from Europe («Siberian» species), nor from Russia. Concerning types of ranges, the proportion of species having predominantly Siberian / East Palaearctic / Siberian-Nearctic ranges varied in different model groups from $0 \%$ to $30 \%$. The fraction of arctic (in a wide sense) species ranged from $0 \%$ to $29 \%$. We considered the status of the natural environment of the Nenetsky Autonomous Okrug to be satisfactory so far as its destruction is particularly local. We strongly confirm the need to create new Protected Areas. The material obtained during the project processing has been applied to the organisation of sanctuaries in the Khaipudyrskaya Bay and Pakhancheskaya Bay, Barents Sea.

Key words: biological value, fauna, flora, geobotanical subdivision, local flora, map, marshes, Protected Area, technogenic pressure 